(0)

(C) Birkhäuser Verlag, Basel, 2008

\title{
Review
}

\section{The genomic basis of the Williams - Beuren syndrome}

\author{
C. Schubert \\ Institute of Human Genetics, Georg-August-University of Goettingen, Heinrich-Dueker-Weg 12, \\ 37073 Goettingen (Germany), Fax: +49-551-39 7567, e-mail: cschube@gwdg.de
}

Received 11 July 2008; received after revision 15 October 2008; accepted 16 October 2008

Online First 26 November 2008

\begin{abstract}
The Williams-Beuren syndrome is a genomic disorder (prevalence: $1 / 7,500$ to $1 / 20,000$ ), caused by a hemizygous contiguous gene deletion on chromosome 7q11.23. Typical symptoms comprise supravalvular aortic stenosis, mental retardation, overfriendliness and visuospatial impairment. The common deletion sizes range of 1.5-1.8 mega base pairs (Mb), encompassing app. 28 genes. For a few genes, a genotypephenotype correlation has been established. The bestexplored gene within this region is the elastin gene; its haploinsufficiency causes arterial stenosis. The region
\end{abstract}

of the Williams-Beuren syndrome consists of a single copy gene region $(\sim 1.2 \mathrm{Mb})$ flanked by repetitive sequences - Low Copy Repeats (LCR). The deletions arise as a consequence of misalignment of these repetitive sequences during meiosis and a following unequal crossing over due to high similarity of LCRs. This review presents an overview of the WilliamsBeuren syndrome region considering the genomic assembly, chromosomal rearrangements and their mechanisms (i.e. deletions, duplications, inversions) and evolutionary and historical aspects.

Keywords. Williams-Beuren syndrome, non-allelic homologous recombination, deletion, duplication, 7q11.23, elastin gene, supravalvular aortic stenosis, LCR.

\section{Introduction}

Clinical symptoms. The Williams-Beuren syndrome (WBS) is a rare genomic disorder $(1 / 7,500-1 / 20,000)$ caused by a hemizygous deletion of contiguous genes on chromosome 7q11.23 [1]. It was first described in the nineteen-fifties by Fanconi, Lightwood and Payne as "Idiopathic infantile hypercalcaemia with failure to thrive" [2-4]. WBS patients clinically display a characteristic pattern of symptoms including vascular stenosis (predominantly supravalvular aortic stenosis (SVAS)), weakness of connective tissue, a typical face, short stature and mental retardation [5-7]. Facial symptoms include a wide mouth with full cheeks and full lips and periorbital fullness with a broad forehead. The cardiovascular manifestations comprise SVAS and peripheral artery stenosis, which occur in $75 \%$ of affected children [8]. Developmental delay is distinct in tasks requiring complex visual analysis for receiving information, whereas WBS patients perform better on tasks with auditory input and verbal output [9]. The typical behavioural features such as poor social relationships, overfriendliness, high sociability and empathy persist usually from childhood to adulthood [10-12]. There is a clear weakness in daily living skills and motor abilities in patients with WBS [13-15]. The IQ range varies from severe mental retardation to a nearly normal level (mean value 57) and attention deficit hyperactivity disorder (ADHD) is common [16]. Typical cranial abnormalities are not frequent in WBS patients except for an unspecific decreased parieto-occipital lobe volume [17, 18]. Additional universal clinical symptoms are intermittent hypercalcaemia, hypertonia, renal anomalies, dental problems (malocclusion), scoliosis/kyphosis, and joint limitation $[19,20]$. Studies on monozygotic twins 
suffering from WBS revealed that most clinical signs, i.e. cardiac defects and abnormal behavioural features are concordant, whereas birth weight, stature and grade of mental retardation seem to be influenced also by environmental factors [21].

Adults with WBS suffer predominantly from the consequences of cardiac defects and hypertension, sensorineural hearing loss, subclinical hypothyroidism, gastrointestinal problems and urinary tract abnormalities. Progressive joint limitation affects coordination and motor skills $[12,16,22]$. Furthermore, a high frequency of psychiatric symptoms, such as anxiety and depression, are noticeable. Independent living and employment are limited by their mental handicap and by their physical problems [16, 23-25].

\section{The history of the Williams-Beuren syndrome}

The genetic cause of WBS remained unclear until the nineteen-nineties. At the beginning, several unbalanced chromosomal anomalies, not involving chromosome 7 , have been identified in WBS-affected children, and were misleadingly suspected to cause the disease [26-28]. A first hint of the genetic basis of WBS was given by the identification of the elastin gene $(E L N)$ in 1993 in a case of familial SVAS segregating with a reciprocal translocation involving chromosomes 6 and 7, which disrupted the ELN gene [29]. This gene was mapped to chromosome 7q11.2 two years before in 1991 [29]. Based on the phenotypic similarity between SVAS and WBS, it was hypothesized that haploinsufficiency for $E L N$ was also the cause of WBS and deletion of ELN was subsequently demonstrated [29, 31-35]. Several studies that followed confirmed and consolidated the previous findings of hemizygousity of the ELN gene as a major cause of WBS. Fluorescence in-situ hybridisation (FISH) analysis with probes for the elastin locus emerged to become the standard method for WBS diagnosis [36-40]. A number of subsequent analyses based on microsatellite DNA markers supported the former hypothesis of a contiguous gene disorder in patients with WBS. PCR-based genotyping of several microsatellite markers around the elastin locus revealed an extended deletion size of several hundred kilo base pairs (kb) [41]. The DNA marker D7S489, located near the ELN gene, shows a high homology to other loci related to the deletion region, therefore it was suspected that repetitive sequences flanking the deletion region could play a role in the mutational mechanism of WBS [42]. An initial physical map of the telomeric part of the WBS region (of $\sim 500 \mathrm{~kb}$ in size) encompassed the genes ELN, LIMK1, RFC2 and other putative transcripts (WBSCR (Williams-Beuren
Syndrome Chromosomal Region) 1-5), which are commonly deleted in patients with WBS [43-46]. In an effort to discover genes whose haploinsufficiency may explain the diversified phenotype of WBS and to determine the deletion size of the WBS locus, numerous studies of gene identifications were published in the second period of the nineteen-nineties [12, 47-77]. The physical map of the WBS deletion locus became more and more complete (Table 1).

\section{Genomic rearrangements and mutational mechanisms in WBS}

Deletions. To date twenty-eight coding genes have been identified within the WBS deletion region, which is composed of a single copy gene region of $\sim 1.2 \mathrm{Mb}$ in size flanked by three large low-copy-repeat sequences (LCR), arranged in LCR blocks A, B and C. These blocks are ordered in complexes, which are located on the centromeric (cen), the medial (mid) and on the telomeric (tel) part of the WBS locus (A-B-C cen, A$\mathrm{B}-\mathrm{C}$ mid and A-B-C tel). Each of these complexes, consisting of one of each block, has a size of approximately $320 \mathrm{~kb}$. Common deletions in WBS patients span a genomic region of around $\sim 1.5 \mathrm{Mb}$ with suspected breakpoints within the centromeric and medial LCR block B [72-78] (Figs. 1 and 2).

Deletions occur regardless of the parental origin of the disease-transmitting chromosome; furthermore, there is no support for imprinted genes within the common deletion region $[42,62,72,73,78-83]$. Usually, WBS occurs sporadically, but a few cases of autosomal dominant inheritance have been reported. In these described families the disease-transmitting parent presented only a mild or oligosymptomatic pattern of WBS [84-87]. However, in some case-reports the clinical diagnosis of autosomal dominant inheritance of WBS was assumed based only on the fact of familial accumulation of WBS symptoms and was not confirmed by cytogenetic analysis $[85,86]$.

Atypical deletions with smaller and larger deletionsizes have also been reported. According to the literature, about $5 \%$ of typical WBS-patients display a deletion of $\sim 1.8 \mathrm{Mb}$, which is caused by recombination between the centromeric and medial LCR block A copies [72, 73, 78, 88, 89]. Furthermore, there are many reports on patients displaying deletions of partial sizes with breakpoints within the single copy region of the WBS. The detected deletion sizes range between $0.1 \mathrm{Mb}-1 \mathrm{Mb}$. The phenotypes presenting by these patients vary between isolated SVAS in small deletions including only the ELN gene and the full spectrum of WBS in deletion sizes of up to $1 \mathrm{Mb}$ [43, 89-96]. It seems that partial deletions encompassing 
Table 1.

\begin{tabular}{|c|c|c|c|c|c|c|c|c|c|}
\hline $\begin{array}{l}\text { Position } \\
\text { Chr. } 7 \text { in Kb, }\end{array}$ & & $\begin{array}{l}\text { LCR } \\
\text { block }\end{array}$ & Genes & Strand & Type & $\begin{array}{l}\text { Ampl. } \\
\text { qPCR }\end{array}$ & $\begin{array}{l}\text { STS } \\
\text { marker }\end{array}$ & & \\
\hline 5 & 3 & & & & & & & & \\
\hline 71.936 & 71.677 & & TYW1B & - & unknown & 71.642 & & & \\
\hline 71.938 & 71.942 & & $S B D S P$ & + & non-coding & & D7S2749 & & \\
\hline 71.977 & 71.971 & & WBSCR19 & - & non-coding & & & & \\
\hline 71.988 & 72.057 & & POMI2I & + & coding & 72.004 & D7S789 & & \\
\hline 72.063 & 72.057 & క & NSUN5C & - & coding? & & & & \\
\hline 72.078 & 72.068 & ن & TRIM74 & - & coding & & D7S1778 & & \\
\hline 72.078 & 72.080 & & FKBP6-like & + & non-coding & & & & \\
\hline 72.114 & 72.107 & & STAG3L3 & - & non-coding & 72.099 & D7S489C & & \\
\hline 72.115 & 72.122 & & $P M S 2 L$ & + & non-coding & & & & \\
\hline 72.138 & 72.128 & छี & WBSCR 19 & - & non-coding & & & & \\
\hline 72.146 & 72.150 & 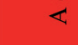 & $P M S 2 L$ & + & non-coding & & & & \\
\hline 72.164 & 72.156 & & WBSCR 19 & - & non-coding & & & & \\
\hline 72.207 & 72.259 & $=$ & GTF2IP & + & non-coding & & & & 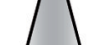 \\
\hline 72.273 & 72.282 & 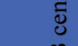 & $N C F 1 B$ & + & non-coding & & & & 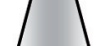 \\
\hline 72.324 & 72.295 & $\infty$ & GTF2IRD2P & - & non-coding & & & & 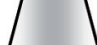 \\
\hline 72.347 & 72.356 & & POM12IB & + & non-coding & & & & \\
\hline 72.361 & 72.355 & ?] & NSUN5 & - & coding & & & 1 & \\
\hline 72.380 & 72.364 & Uี & TRIM50 & - & coding & 72.366 & D7S1778 & 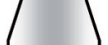 &.$\sqsubseteq$ \\
\hline 72.380 & 72.411 & & FKBP6 & + & coding & & & $(1)$ & $\risingdotseq$ \\
\hline 72.486 & 72.488 & & FZD 9 & + & & & D7S489B & 응 & 3 \\
\hline 72.575 & 72.492 & & $B A Z 1 B$ & - & & 72.496 & D7S2024 & & $\stackrel{\infty}{+}$ \\
\hline 72.610 & 72.589 & & $B C L 7 B$ & - & & & & $\bar{\sigma}$ &.$\overline{\bar{n}}$ \\
\hline 72.631 & 72.621 & g & $T B L 2$ & - & & & & $\geq$ 光 & 응 \\
\hline 72.677 & 72.645 & : & $M L X I P L$ & - & & & D7S1624 & 톨 으 & $\frac{2}{x}$ \\
\hline 72.720 & 72.724 & ț & VPS37D & + & & & & $3 \overline{0}$ & (1) \\
\hline 72.736 & 72.733 & 离 & DNAJC3O & - & & & & 윽 $\frac{\alpha}{1}$ & 흔 \\
\hline 72.736 & 72.750 & లี & WBSCR22 & + & & & & $\geq 0$ & $\underline{\underline{1}}$ \\
\hline 72.772 & 72.751 & ज्ञ & $S T X 1 A$ & - & & & & 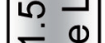 & $\overline{0}$ 함 \\
\hline 72.791 & 72.788 & है & $A B H D 11$ & - & & & & $\begin{array}{ll}5 & \pm \\
& \end{array}$ & - 은 은 \\
\hline 72.823 & 72.821 & $\stackrel{\text { जี }}{=}$ & $C L D N 3$ & - & coding & 72.874 & & 든 & $\bar{\nabla} \stackrel{\sim}{>}$ \\
\hline 72.883 & 72.885 & $\bar{z}$ & CLDN4 & + & & & & $\stackrel{\Xi}{N}$ & $=3$ \\
\hline 72.795 & 72.887 & 4 & WBSCR 27 & - & & & D7S613 & क & 紊 \\
\hline 72.913 & 72.918 &. & WBSCR 28 & + & & & & $\begin{array}{ll}5 & 0 \\
0 & 0\end{array}$ & $\begin{array}{ll}3 & 0 \\
0 & 0\end{array}$ \\
\hline 73.080 & 73.122 & 总 & ELN & + & & 73.091 & & 을 몸 & 를 유 \\
\hline 73.136 & 73.175 & 2. & LIMKI & + & & & & 包 & $\begin{array}{ll}2 & 0 \\
\infty & 0\end{array}$ \\
\hline 73.227 & 73.249 & 8 & EIF $4 H$ & + & & & D7S613 & $\frac{1}{0}$ 음 & ${ }^{\infty} \cdot 1$ \\
\hline 73.262 & 73.282 & $\frac{0}{40}$ & LAT2 & + & & & D7S489 & 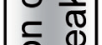 & 4 \\
\hline 73.307 & 73.284 & 施 & $R F C 2$ & - & & 73.307 & & 읃 잉 & (1) U \\
\hline 73.342 & 73.458 & & CLIP2 & + & & & & & $\stackrel{\mathbb{N}}{\mathrm{N}}$ 음 \\
\hline 73.506 & 73.655 & & GTF2IRD1 & + & & & D7S2472 & & ๘ \\
\hline 73.585 & 73.585 & & WBSCR23 & + & unknown & & & 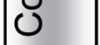 & 두 \\
\hline 73.710 & 73.812 & $\tau$ & GTF2I & + & coding & 73.774 & D7S1870 & & .0 \\
\hline 73.826 & 73.842 & 鄫 & $N C F 1$ & + & coding & & & & $\frac{\Phi}{\Phi} \overline{0}$ \\
\hline 73.906 & 73.848 & $\overline{0}$ & GTF2IRD2 & - & coding & 73.928 & & & வ \\
\hline 73.945 & 73.937 & $\tau$ & STAG3L2 & - & non-coding & & D7S489A & & \\
\hline 73.945 & 73.960 & 光 & $P M S 2 L 5$ & + & non-coding & & & & \\
\hline 73.976 & 74.077 & $\varangle$ & GATS-L & + & non-coding & & & & \\
\hline 74.128 & 74.094 & & WBSCR16 & - & coding & 74.119 & & & \\
\hline 74.146 & 74.203 & & GTF 2 IRD $2 B$ & + & coding & & & & \\
\hline 74.226 & 74.210 & $\bar{\Xi}$ & NCF1C & - & non-coding & & & & \\
\hline 74.291 & 74.239 & & GTF2IPI & - & non-coding & & & & \\
\hline
\end{tabular}

Summary of single genes within the WBS region. Displayed are the gene name, chromosomal positions, transcription direction and gene type. In addition, a selection of known STS-markers within this region is depicted in the right column. Furthermore, the right column displays in grey positions the different PCR-amplicons (Ampl.qPCR) used in the deletion screening in Schubert C et al. 2006 [97]. Information derived from the Build $36.3 \mathrm{National} \mathrm{Center} \mathrm{for} \mathrm{Biotechnology} \mathrm{Information.} \mathrm{In} \mathrm{this} \mathrm{assembly,} \mathrm{a} \mathrm{gap} \mathrm{exists} \mathrm{of} \sim 250 \mathrm{~Kb}(\mathrm{Chr}$. 7: $74,350 \mathrm{~Kb}$ to $74,600 \mathrm{~K}$ ) with no information about genomic organisation of this region. Beside the table, in vertical arrows, the common deletion size of $\sim 1.5 \mathrm{Mb}$ and the more rare deletion size of $\sim 1.8 \mathrm{Mb}$ in WBS patients are depicted. In the common deletions, breakpoints occur within the LCR block B, in the case with a larger deletion a recombination occurs within the LCR blocks A cen and A mid. These NAHR events affect 26 coding genes that are invariably deleted. In addition to these 26 genes, NCF1 and GTF2IRD2 can be variable deleted depending on the NAHR locus within block B or - A. Larger and smaller atypical deletion sizes in patients with the full or a partial clinical spectrum have also been described (not displayed in the picture, for more information see text passage). 
Table 1. (continued)

\begin{tabular}{|c|c|c|c|c|c|c|c|}
\hline $\begin{array}{l}\text { Position } \\
\text { Chr. } 7 \text { in Kb, }\end{array}$ & & $\begin{array}{l}\text { LCR } \\
\text { block }\end{array}$ & Genes & Strand & Type & $\begin{array}{l}\text { Ampl. } \\
\text { qPCR }\end{array}$ & $\begin{array}{l}\text { STS } \\
\text { marker }\end{array}$ \\
\hline 5 & $3^{\prime}$ & & & & & & \\
\hline 74.333 & 74.342 & & WBSCR 19 & + & non-coding & & \\
\hline 74.353 & 74.339 & & $P M S 2 L$ & - & non-coding & & \\
\hline 74.604 & 74.628 & & $R C C I L$ & + & non-coding & & \\
\hline 74.706 & 74.646 & & GATS-L & - & non-coding & & \\
\hline 74.749 & 74.757 & $\bar{\Xi}$ & WBSCR 19 & + & non-coding & & \\
\hline 74.783 & 74.774 & $\ll$ & WBSCRI9 & - & non-coding & & \\
\hline 74.795 & 74.791 & & $P M S 2 L$ & - & non-coding & & \\
\hline 74.805 & 74.813 & & WBSCR 19 & + & non-coding & & \\
\hline 74.823 & 74.819 & & $P M S 2 L$ & - & non-coding & & \\
\hline 74.826 & 74.835 & & STAG3L1 & + & non-coding & & D7S489C \\
\hline 74.863 & 74.859 & & FKBP6-like & - & non-coding & & \\
\hline 74.863 & 74.873 & $\bar{\Xi}$ & TRIM73 & + & coding & & D7S1778 \\
\hline 74.877 & 74.884 & U & NSUN5B & + & coding? & & \\
\hline 74.953 & 74.884 & & POM121C & - & coding & & D7S789 \\
\hline 74.962 & 74.972 & & WBSCRI9 & + & non-coding & & \\
\hline 74.995 & 74.975 & & $P M S 2 L 3$ & - & non-coding & & \\
\hline 75.206 & 75.001 & & $H I P$ & - & coding & & \\
\hline
\end{tabular}

the telomeric part of WBS region distal to the ELN gene cause a more severe phenotype than partial deletions, which encompass the part centromeric to the ELN gene [43, 93-95]. In our qPCR-analysis of patients with the clinical suspicion of WBS, the deletion-sizes range between $\sim 0.2 \mathrm{Mb}$ to $\sim 2.5 \mathrm{Mb}$, whereas $90 \%$ of deletion-positive patients carry a deletion in the range from 1.4 to $1.9 \mathrm{Mb}$. It is suggested that patients with a deletion size of $\sim 1.4$ to $\sim 1.6 \mathrm{Mb}$ display the deletion breakpoints within the LCR blocks B cen and B med, whereas the breakpoints of a deletion size of $\sim 1.7$ to $\sim 1.9 \mathrm{Mb}$ are within the centromer and medial LCR block A [78, 97] (Fig. 1, Table 1).

The deletions in the WBS region arise as a consequence of misalignment of gametes during meiosis following unequal crossing over (NAHR - non-allelic homologous recombination) due to high similarity of LCR blocks, especially block B (Fig. 3A and B).

About $5 \%$ of the entire human genome contains LCRs with a relatively large size $(>10 \mathrm{~kb})$ and with high sequence identity (>95\%) [98]. It is suggested that regions of high sequence identity are required to facilitate NAHR and that a certain length of perfectly matched sequences is necessary for efficient NAHR [99-101]. Interchromosomal or interchromatid recombination of misplaced aligned chromosomal regions (different LCR blocks) with high sequence identity and the same orientation will lead to a deletion and a reciprocal duplication of the genomic region located between the repeated regions (Fig. 3A). Intrachromatid NAHR generates a deletion and a reciprocal circular acentric chromosome (Fig. 3B). It is assumed that the highest rates of NAHR occur at repeats with a close distance and high

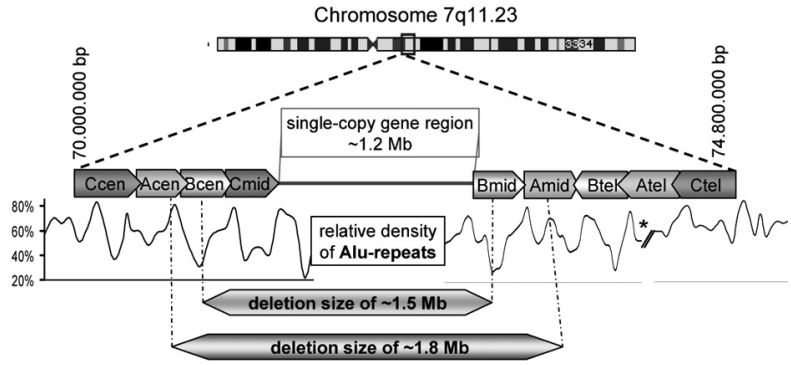

Figure 1. Graphical view of the Williams-Beuren-Deletion region on chromosome 7q11.23. The location and orientation of the lowcopy-repeat (LCR) blocks A-C are depicted in arrows. The base pairs positions (bp) are predicted on Build 36.3, National Center for Biotechnology Information. Underneath the relative density of Alu-repeats in the section of LCR, blocks are shown. A high density of $A l u$-repeats is present at the outer edges of the blocks, indicating Alu-mediated rearrangements during evolutionary development of the WBS region. The horizontal arrows display the common deletion sizes of $\sim 1.5 \mathrm{Mb}$ and $\sim 1.8 \mathrm{MB}$ with breakpoints within the centromeric and the medial copy of LCR block B and within the centromeric and the medial copy of LCR block A, respectively. *In the current assemblies of the human genome, a gap exists of $\sim 250$ $\mathrm{Kb}(\mathrm{Chr} .7: 74,350 \mathrm{~Kb}$ to $74,600 \mathrm{~Kb})$ with no information about the genomic organisation of this region

similarity [101-103]. Haplotype analyses in families with an affected child with WBS revealed that twothirds of the cases the chromosomal misalignment seems to result from interchromosomal reshuffling between homologous chromosomes 7 and in one-third of cases from an intrachromosomal (inter- or intrachromatid) rearrangement between sister chromatids $[79,80,82]$. Breakpoint-specific sequencing of the WBS region in sperm revealed that interchromatid recombination is much less frequent than intrachromatid or interchromosomal recombination. Investigation of sperm samples for deletion- and duplication rates in the WBS locus revealed a deletion rate of $\sim 1 \mathrm{x}$ 


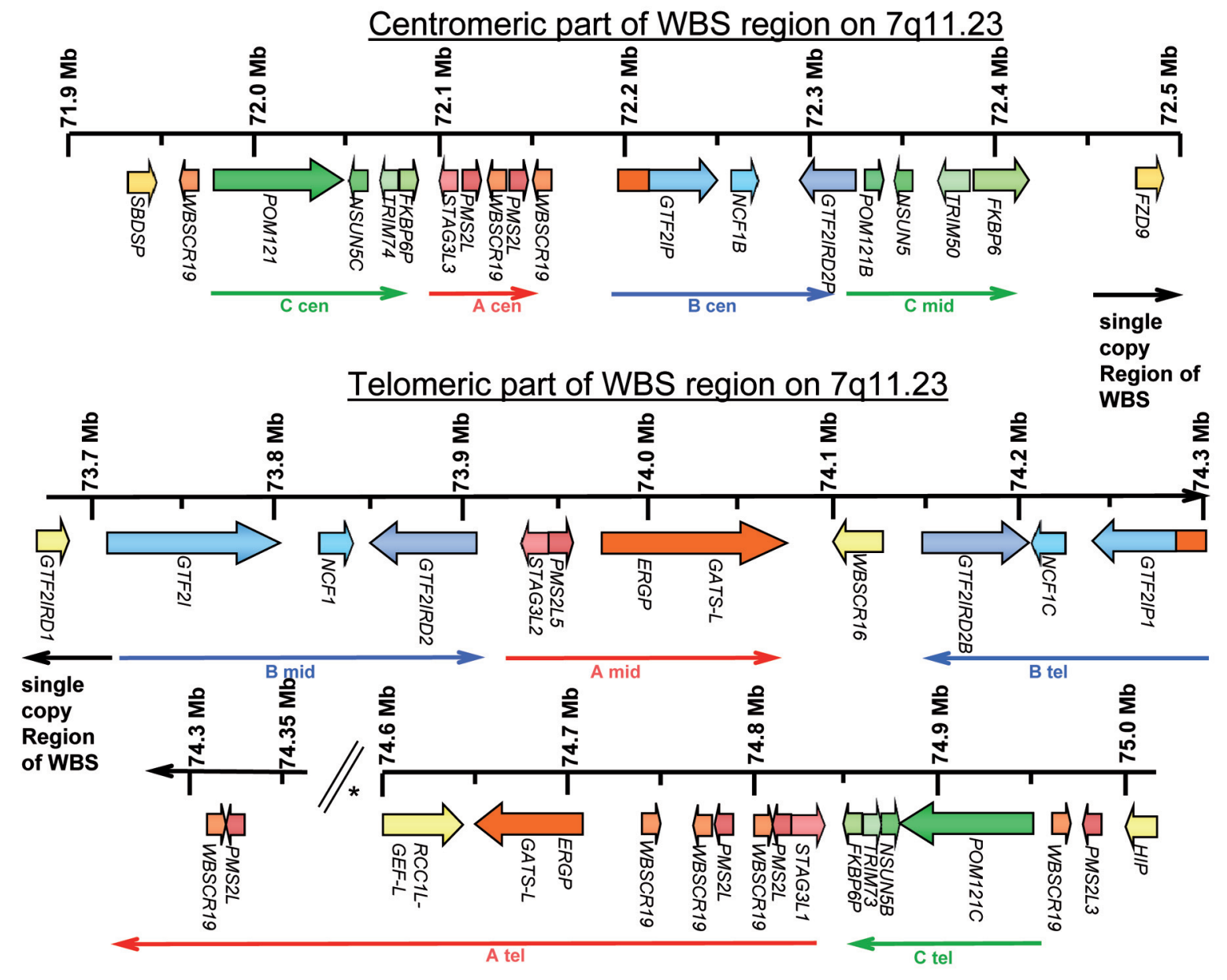

\section{of WBS region on $7 q 11.23$}

Figure 2. Graphic of the centromeric and telomeric genomic region of LCR blocks of the WBS locus: Displayed are the single genes in their position in megabases $(\mathrm{Mb})$ on chromosome 7 and their orientation within the WBS region. The genes comprised to one LCR-block are indicated with colored arrows underneath: red: LCR blocks A, blue: LCR blocks B, green: LCR blocks C. The base pairs positions (bp) are predicted on Build 36.3 National Center for Biotechnology Information http://www.ncbi.nlm.nih.gov. and assembly March 2006 by The UCSC Genome Browser Database http://genome.ucsc.edu/index.html ). *In the current assemblies of the human genome, a gap exists of $\sim 250 \mathrm{~Kb}(\mathrm{Chr}$. 7: 74,350 Kb to 74,600 Kb) with no information about the genomic organisation of this region.

$10^{-5}$ and a duplication rate of $5 \times 10^{-6}$, leading to a deletion-duplication rate of $2: 1$. The higher deletion frequency could be explained by the high rate of intrachromatid recombination leading to a deletion and a reciprocal acentric chromosome, but not to a duplication of the WBS region. This germline-related deletion rate encompasses the disease-based estimated prevalence of WBS of $1 / 7,500$ to $1 / 25,000$. It has to be mentioned that in this assay only one specific sequence within the LCR block B has been used for recombination studies. Several recombination hot spots have been identified within the blocks B and $\mathrm{A}$, the deletion/duplication rates at these sites may be different [103].

Breakpoint studies in patients carrying a $\sim 1.5 \mathrm{Mb}$ deletion revealed that the majority of samples displayed breakpoints within the genes GTF2IP1 (B cen) and GTF2I (B mid), whereas some cases presented breakpoints in the genes $N C F 1 B$ (B cen) and $N C F 1$ (B mid) and several cases within the genes GTFIRD2P (B cen) and GTFIRD2 (B mid). The authors of this study assume that the high sequence homology of the blocks B cen and B mid predisposes for non-allelic homologous recombination. The overall sequence identity of B cen and B mid is $99.6 \%$, in contrast to a sequence identity of $98.2 \%$ between blocks A cen and A mid with two large deletions of $15 \mathrm{~kb}$ and $26 \mathrm{~kb}$ in block A mid. Furthermore, the interval size between blocks $\mathrm{B}$ cen and $\mathrm{B}$ mid is shorter $(\sim 1.5$ $\mathrm{Mb})$ than between the block $\mathrm{A}$ cen and $\mathrm{A}$ mid $(\sim 1.8$ $\mathrm{Mb})$. This reduced interval size is also suspected to promote rearrangements involving predominantly blocks B cen and B mid [78] (Figs. 1 and 2).

Inversions. In the population of WBS patients, about $30 \%$ of the chromosome-transmitting parents are 
A Interchromosomal / interchromatid NAHR

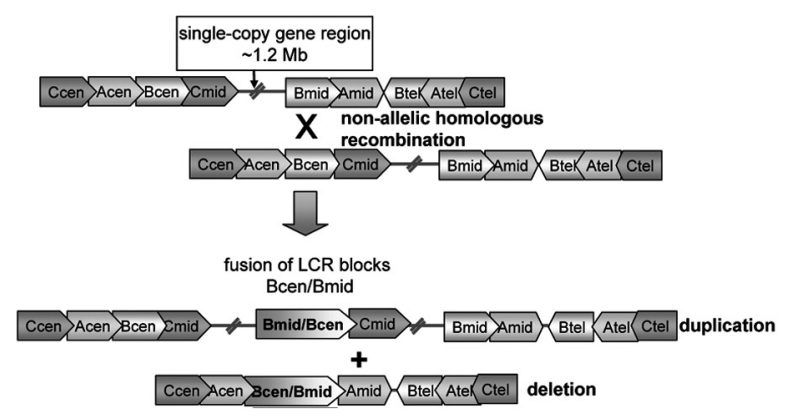

B

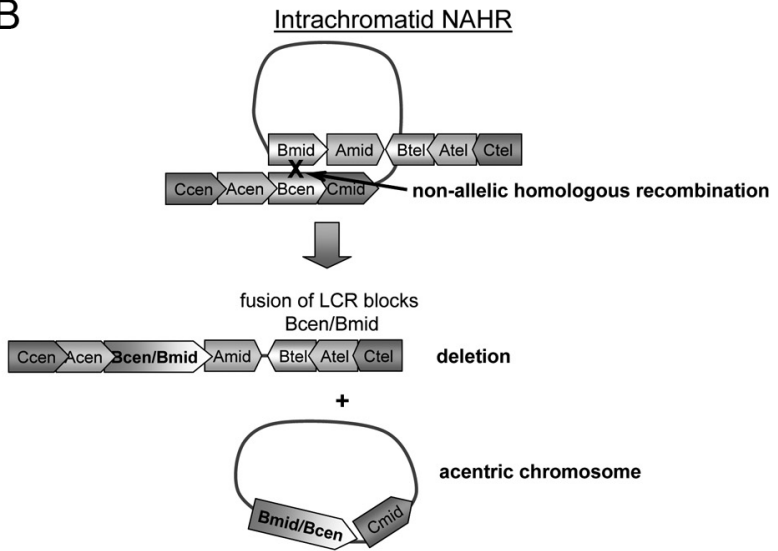

Figure 3. (A) Interchromosomal or interchromatid NAHR between the LCR block B mid from one chromosome and block B cen from the sister-chromosome or -chromatid. Unequal crossing over results in a deletion and a reciprocal duplication of the WBS region with creation of a fusion of LCR block B cen and B mid. $(B)$ Intrachromatid NAHR between the LCR blocks B mid and B cen from the same chromatid. Unequal crossing over results in a deletion of the WBS region with creation of a fusion of LCR block $\mathrm{B}$ cen and $\mathrm{B}$ mid and a reciprocal acentric chromosome with high risk for segregation loss.

carriers of a paracentric inversion of the WBS locus on chromosome 7 with breakpoints external to the WBS single copy gene region, which does not disrupt any actively expressed genes [78, 104]. In the non-WBS population, this inversion is present in about $5 \%$ [104, 105]. The inversion is generated by meiotic or mitotic intrachromatid misalignment between the inverted homologous centromeric and telomeric LCR blocks, resulting in a non-allelic homologous recombination between the paired LCR blocks. This can occur in each of the LCR blocks, resulting in a variable sized paracentric inversion $(1.8-2.9 \mathrm{Mb})$ [78, 104-107] (Fig. 4A).

Presence of this inversion predisposes to chromosomal mispairing in meiosis. An interchromosomal or interchromatid NAHR event between an inverted and a non-inverted chromosome would result in a deletion and a reciprocal duplication of the WBS region (Fig. 4B). In contrast, in NAHR under participation of an inverted chromosome the sizes of perfect matched sequences is increased due to two misaligned LCR blocks instead of only one LCR block in chromosome pairing of two non-inverted chromosomes (Fig. 3A and 4B).

Additionally, Bayes and co-workers created a different model for the occurrence of a WBS deletion by chromosomal mispairing of an inverted and a noninverted chromosome. Thereafter (analogous to the typical loop-formation of chromosomes with paracentric inversions during chromosomal pairing) a pairing of an inverted and a non-inverted WBSchromosome would produce a loop of the single-copy gene region of WBS and a misalignment of LCR blocks. A deletion or a reciprocal duplication of the WBS region would occur, if an unequal crossing-over arise between the misaligned blocks $\mathrm{B}$ tel and $\mathrm{B}$ mid, derived either from the inverted chromosome or from the non-inverted chromosome. A crossing over within the loop of the single-copy region of the WBS region would result in either an acentric or a dicentric chromosome 7 with high risk for fetal loss [78] (Fig. 4C).

On a formal genetic basis the recurrence risk of a WBS-inversion carrier for a child with WBS is up to 1 : 500 , due to a recombination rate of up to $0.2 \%$ in the non-allelic misaligned fragments (two LCR blocks each with a size of $\sim 100 \mathrm{~kb}$ corresponding to a region specific recombination rate of $0.3-1 \%$ per $1 \mathrm{Mb}$ ) [78, 103, 106]. An inhibited formation of chiasmata during meiosis because of the inverted WBS region could further raise the risk of misalignment between nonallelic LCR blocks; thus, individuals carrying the inversion are of higher susceptibility to deletion or duplication during meiosis $[101,107]$.

The presence of this inversion has also been reported for patients displaying symptoms of WBS [104]. However, in a recent study on expression level of genes within the WBS single-copy region revealed no significant differences in gene expression level between individuals without the inversion and healthy inversion-carriers, except for a 1.2-fold elevated STX1A expression in inversion carrier. This suggests that the inversion of the WBS region should not cause clinical symptoms [108].

Duplication. Recently, some case reports described several patients with a duplication of the WBS region, who display as a pathognomonic feature a severe expressive-language delay. In some cases, behavioural abnormalities such as ADHD (Attention Deficit Hyperactivity Disorder) or autism are present. Only mild, not apparently specific anomalies in cranial MRI 
A

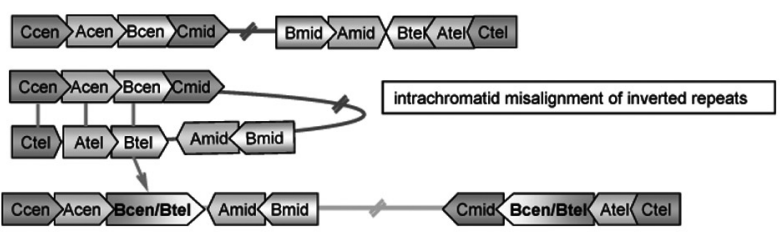

B
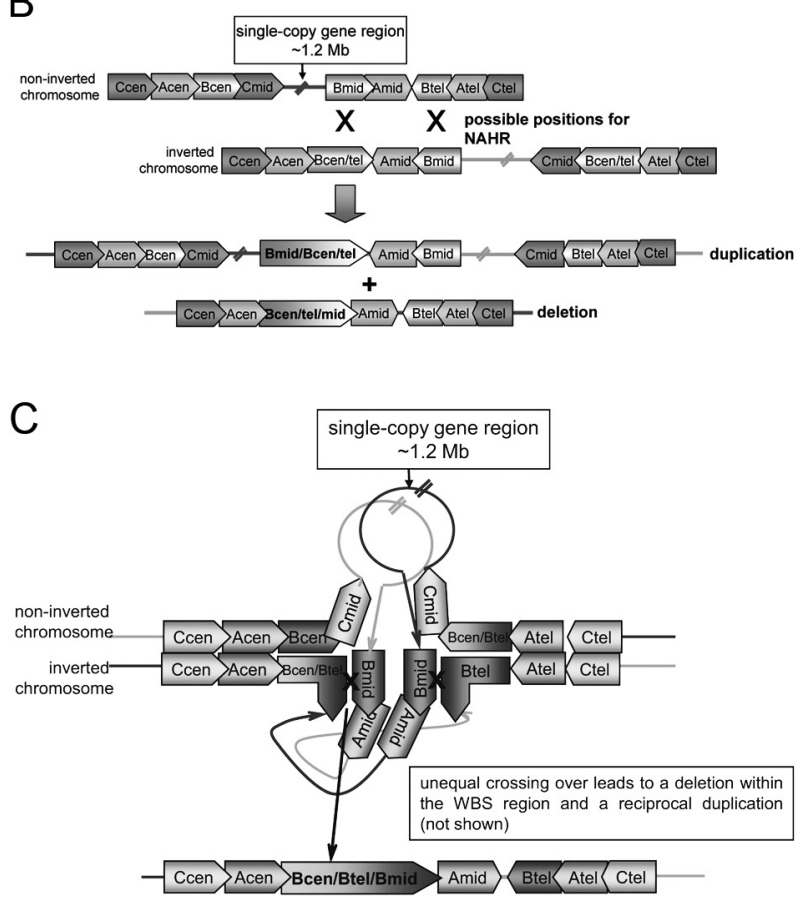

Figure 4. $(A)$ Development of an inversion in the WBS region due to an intrachromatid misalignment of inverted LCR blocks, which leads to an inversion of the WBS region with breakpoints within this block, where the unequal crossover has occurred. In the depiction, a crossover in the B block is illustrated. $(B)$ NAHR between two misaligned blocks $B$ located either on an inverted chromosome or on a non-inverted chromosome. The sizes of perfectly matched sequences is increased due to two misaligned LCR blocks instead of only one LCR block in chromosome pairing of non-inverted chromosomes $(C)$ Modeled after Bayes et al.: Graphic of inter-chromosomal pairing of a normal and an inverted chromosome by producing a loop-formation. Unequal crossing over among the misaligned blocks $\mathrm{B}$ tel and $\mathrm{B}$ mid (x) would lead to the illustrated chromosome with a fusion of repeats of block B with a subsequent deletion or a reciprocal duplication of WBS region (modified after [71]).

(magnetic resonance imaging) and EEG (electroencephalography) are recognizable. No pathognomonic facial dysmorphism seems to be associated with this chromosomal rearrangements, but in some cases synostosis or trigonocephaly with a broad nose, posterior rotated ears, high arched palate and short philtrum are manifest [109-118]. In a third of cases, the duplication is inherited from one parent; in a few of the reported families, the chromosome-transmitting parent displayed a mild pattern of WBS-duplica- tion typical symptoms. This observation of only minor symptoms in the duplication-carrying parent could imply that, in addition to gene dosage effects, other mechanisms such as genetic and/or environmental interactions are important in determining the phenotypic outcome of patients with this genetic aberration $[109,111,116,118]$. Using FISH and quantitative real time PCR, the size of the duplication was calculated generally to be the same size as of the common deletion region in WBS $(\sim 1.5 \mathrm{Mb})$. The breakpoints occur within the LCR blocks B cen and B mid with an increased expression of the genes within the single copy region of WBS [110, 111]. Smaller and larger duplication sizes have also been reported [111, 117, 118]. Duplications within the WBS region are supposed to result from the same mechanism of unequal meiotic recombination as the occurrence of deletions in this region. It has been shown that duplications of the WBS region arise at half the frequency as deletions. So far, only a few cases of duplications have been described in the literature. The clinical presentation associated with reciprocal WBS duplications certainly seems to be milder, and facial features are different and less distinct than those of WBS; thus, presumably more patients exist but remain undiagnosed [103, 110, 118, 119].

\section{Evolution of the Williams-Beuren syndrome region}

It is assumed that the origin of the segmental duplications (LCRs) in the WBS region developed $\sim 25$ Mya (million years ago) after the separation of the macaque from the homonidae $[76,120]$. The common ancestral chromosome of 7q11.23 in macaque differs only marginally from the syntenic region in mouse. The divergence of rodents and primates is estimated at $\sim 80$ Mya ago, demonstrating the absence of large chromosomal rearrangements in this period. It has been shown that the human LCR blocks are absent in mouse. The orthologous genes are single loci mapped on mouse chromosome 5G1. The order of intradeletion located genes relative to extradeletion loci is inverted with respect to the human genome map [73, $76,88,120,121]$.

The ancestral chromosome present in the macaque line consists of the blocks B and C flanking the entire coding region of WBS. After divergence of the homonidae from the macaque species a first paracentric inversion between $7 \mathrm{q} 11$ and $7 \mathrm{q} 22$ occurred with breakpoints at the outer edges of the blocks B and $\mathrm{C}$ next to the formation of block $\mathrm{A}$ by a duplication of an ancestral gene (STAG3) in 7q22 [122]. Block A (in the human genome the telomeric LCR block A) was oppositely oriented to the primor- 
dial blocks B (in the human genome the medial LCR block $\mathrm{B}$ ) and $\mathrm{C}$ (in the human genome the centromeric LCR block C). A first duplication of block $\mathrm{C}$ (in the human genome the telomeric LCR block C) arose further between the first LCR block A and the HIP1 gene which is a single copy gene next telomeric to the WBS region. This primordial chromosome of the WBS locus is common with small differences from the main lineages of non-human homonidae, i.e. gorilla, orangutan and chimpanzee. In the human genome, some Alu-mediated transpositions and other intrachromosomal rearrangements due to inverted repeats occurred during the separation from the non-human homonidae. A first misalignment through Alu-mediated transposition is proposed to have resulted in duplication of the medial LCR block $A$ and the telomeric LCR block B. In addition, it is supposed that an inversion occurred in this intermediate chromosome by an intrachromosomal rearrangement between inverted repeats. An interchromosomal nonallelic homologous recombination between an inverted intermediate chromosome and a non-affected intermediate chromosome could have led to the final human chromosome of the WBS region $[76,120]$ (Fig. 5).

\section{The low copy repeats (LCR) of the WBS region}

The WBS deletion locus on 7q11.23 is a region with a high density of chromosome 7 specific segmental genomic duplications. In part, these duplications are either shaped as tandem repetitions or they derived as duplication from other genomic regions of chromosome 7 [96]. In general, chromosome-specific LCRs appear to be enriched in centromeric- and subtelomere regions [99, 123]. The single copy region of WBS is flanked by such segmental duplications (low copy repeat sequences - LCR), arranged in three LCRblocks, namely A, B and C (Fig. 1).

Previously, it has been shown that a significant representation of $\mathrm{Alu}$ repeats is positioned at the boundaries of these segmental duplications [124]. Alu repeats are repetitive short interspersed nuclear elements (SINE) of less than 500 base pairs (bp) in size, containing a recognition site for the restriction enzyme Alu [125]. Depending on their appearance, they can be categorized into three different subfamilies - AluJ, AluS and AluY [124]. Alu repeats are suspected to be predisposing regions for homologous recombination, which result in various genetic exchanges, including duplications, deletions, and translocations [126]. The existence of Alu elements at the junction region of the large duplicated blocks in 7q11.23 indicates that $A l u$-mediated genome shuffling may have contributed to the final generation of these large segmental duplications [120].

The single copy gene region is located between the blocks $\mathrm{C}$ mid and $\mathrm{B}$ mid and spans a region of $\sim 1.2 \mathrm{Mb}$. The centromeric and the telomeric LCR block order is $\mathrm{C}>\mathrm{A}>\mathrm{B}$, whereas the transcription direction of the centromeric complex is in the opposite direction to the telomeric complex. The medial LCR complex is composed of the order $\mathrm{C}>\mathrm{B}>\mathrm{A}$ with the same transcription direction as the centromeric block $[73,88,89$, 127] (Figs. 1 and 2). The centromeric, medial and telomeric copies of the single blocks share a high similarity at nucleotide sequence level (98-99\%) with a liability to mispairing and unequal crossover leading to deletions $[78,88]$. The single blocks are composed mainly of truncated copies of genes, coding for pseudogenes, except for some genes, which are transcriptionally active (Table 1).

Results of genotyping analysis using STS (sequence tagged site) markers indicate that the number of LCR blocks flanking the WBS deletion region might be variable among $5 \%$ of WBS-transmitting progenitors $[106,128]$. While three loci of each block are present in most individuals, it has been shown in some cases that block A or block B is present in two or four copies on one chromosome [88, 128]. The rate of copy numbers of LCR blocks is up to 4-fold higher in WBStransmitting progenitors as compared to the control population, thus indicating that this may predispose to the WBS deletion [128].

\section{Genomic region of block $A$}

This block consists of four different pseudogenes: STAG3, PMS2, GATS and the WBSCR19 fragment. These genes are mainly segmental duplications of other regions on chromosome 7 [63, 77, 96]. The ancestral gene of STAG3 and GATS are located on chromosome 7q22, the transcriptionally active gene of PMS2 is positioned on the short arm of chromosome 7 (7p22) [63, 77].

It is suggested that STAG3 is implicated in chromosome pairing during meiosis. Several related STAG3 genes have been mapped to chromosome 7 , three truncated copies are part of block A including the polymorphic STS marker D7S489. The 5' UTR of the STAG3-related genes are flanked by a JTV1-related exon (JTV1RE) showing high similarity to the first exon of the JTV1 gene, which overlaps the PMS2 gene, transcribed in the opposite direction on chromosome $7 \mathrm{p} 22$ [77].

The gene product of PMS2 on chromosome 7p22 functions as a DNA mismatch repair protein and plays a role in hereditary cancer, i.e. Turcot Syndrome and 
(A)

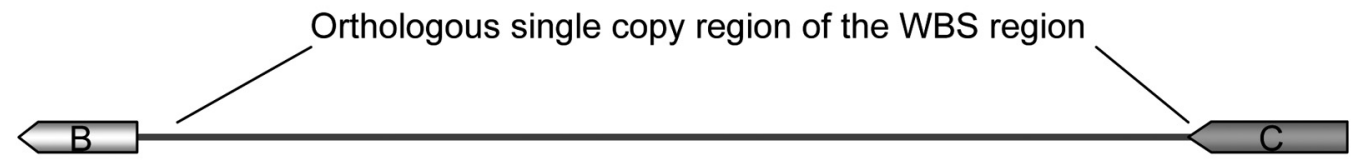

(B)

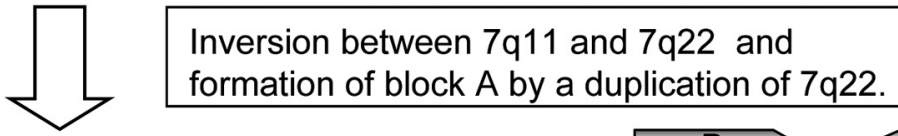

(C)
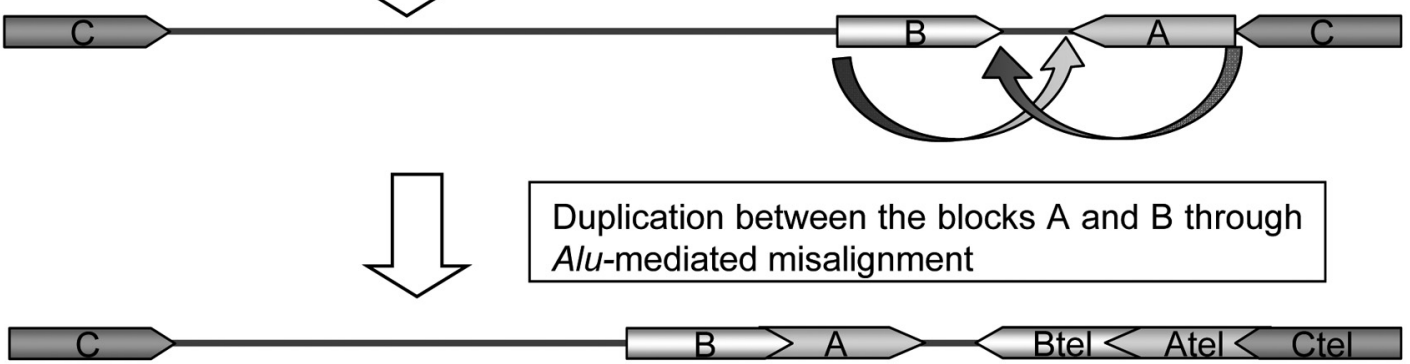

(D)

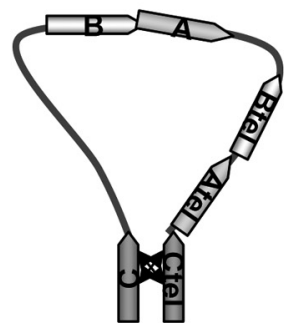<smiles>C1CCCCC1</smiles>

Inversion by intra-chromosomal rearrangement

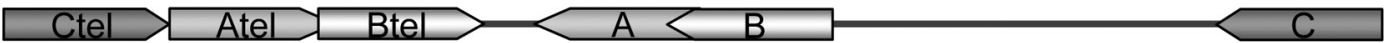

NAHR between an inverted intermediate chromosome and a non-inverted intermediate chromosome

(E)

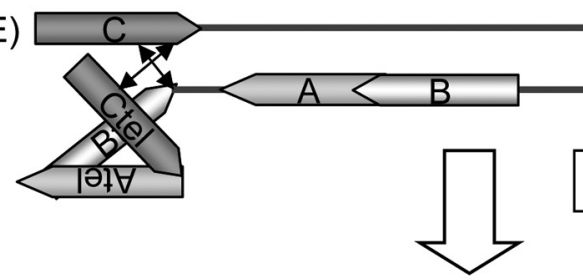

Figure 5. Depiction of the presumed evolutionary development of the human WBS chromosome. (A) After divergence of the homonidae, a first inversion between 7q11 and 7q22 occurred next to the formation of block A by a duplication of an ancestral gene (STAG3) in 7q22. (B) A first duplication of block C between the block A and the HIP1 gene (not shown) arose with the same orientation of block A. ( $C$ ) By a first misalignment through Alu mediated transposition, a duplication between the ancestral blocks A and B, the medial block A and the telomeric B block appeared. $(D)$ An inversion occurred in this intermediate chromosome by an intrachromosomal rearrangement between inverted repeats. $(E)$ An interchromosomal non-allelic homologous recombination (NAHR) between an inverted intermediate chromosome and a non-inverted intermediate chromosome could have led to the final human chromosome of the WBS region (modified after Antonell et al. 2005 [111]). 
Lynch syndrome. Fifteen pseudogene loci of PMS2 exist on chromosome 7, none of them is actively processed. Some of these pseudogene loci are part of the LCR block A in one copy or in two or three repetitions [48, 63, 129, 130]. Most likely, the presence of these truncated copies of STAG3 and PMS2 arose as a consequence of evolutionary chromosomal remodelling [77].

The GATS related sequences are present in the medial and telomeric part of block A. A part of these sequences show a high level of homology to the 5', end of the pseudogenes of GTF2I on LCR block B (called ERGP for exon-related to GTF2I pseudogenes). It is suggested that evolutionary $A l u$-mediated duplication of the block $\mathrm{A}$ and $\mathrm{B}$ has promoted this $E R G P$ in the GATS related sequences (the sequence homology is indicated as the orange part of GTF2IPs in Fig. 2). The function of the ancestral GATS gene on chromosome 7q22 still remains unclear [88].

Furthermore, a genetic fragment, which shares high similarity to WBSCR19 on chromosome $7 \mathrm{p} 13$, is part of block A in a multicopy locus pattern. The functional role of WBSCR19 has not been investigated so far, most of the available information on this gene product based on in-silico analyses and theoretical protein models.

The coding gene WBSCR16 is located at the end of the medial part of block A. This gene encodes an RCC1like G-exchanging factor. A pseudogene of this gene is localised in the telomeric part of block $\mathrm{A}$, in the centromeric part no copy of this region can be found [70] (Fig. 2, Table 1).

\section{Genomic region of block B}

The block B consists of three genes: GTF2I, GTF2IRD2 and NCF1. The transcriptionally active copy of GTF2I, which encodes for a transcription factor (member of the transcription factor family TFII-I), is localised in the medial part of block B. The gene copies of GTF2I in the centromeric and telomeric part are transcribed as truncated proteins [60, $61,89]$. The GTF2IRD2 gene, which is also a member of the TFII-I family, appears to be fully transcribed in parallel by the medial and the telomeric copy of block $\mathrm{B}$, the centromeric copy of GTF2IRD2 is not expressed, lacking the exons 1 and 2 [66]. A third member of this gene family is the GTF2IRD1 gene, which is a single copy locus, located centromeric to the medial copy of this LCR block.

Genomic alignments of these genes suggest that GTF2IRD2 is a truncated version of GTF2I, containing the 5' coding region of GTF2I [131]. GTF2I itself appears to be an evolutionary local duplication of
GTF2IRD1 [67]. It has been shown that GTF2I interacts with GTF2IRD1 [131]. Studies on phenotypic features in patients with partial deletions of WBS region suggest that GTF2I and GTF2IRD1 have overlapping function and are involved in the development of the cognitive-behavioural profile of WBS, especially the severe visuospatial construction deficit and the hypersociability [92, 93, 132]. Immunhistological staining on brain tissues from WBS patients revealed a lack of staining for GTF2I in neurons from the posterior parietal lobe which include parts of the dorsal parietal visual pathway [133]. A distinct phenotypic relation of WBS to GTF2IRD2 haploinsufficiency has not been explored so far. There are some hints that GTF2IRD2 is functionally equal to the other TFII-I family members according to the sequence similarity and the putative same evolutionary origin [66].

NCF1 is one of the NADPH - oxidase components that plays an important role in immune defence. It has its ancestral gene in the medial part of block B. The centromeric and the telomeric part contain gene copies of NCF1, which are expressed as truncated proteins with a very short open reading frame (ORF). Homozygous or compound-heterozygous mutations of this gene cause one form of chronic granulomatous disease, a rare disorder with multi-organ manifestation due to an immunodeficiency $[89,134,135]$. Recent findings suggest a contribution of NCF1 to the development of hypertension. Patients with deletion breakpoints within the NCF1 or GTF2IRD2 genes presented significantly less hypertension than in WBS patients with deletion breakpoint in the GTF2I gene with no hemizygousity of the NCF1 gene. Reduced angiotensin II-mediated oxidative stress related to the aberrant NADPH oxidase activity is assumed to account for this correlation [136, 137] (Fig. 2, Table 1).

\section{Genomic region of block $\mathrm{C}$}

Four genes are present in the LCR block C: POM121, NSUN5, TRIM50 and FKBP6. POM121 is one of the integral membrane components of the nuclear pore complex, which mediates the transport of macromolecules across the nuclear envelope. Recent studies have demonstrated that POM121 proteins are expressed from both centromeric and telomeric gene loci [138].

The ancestral gene of NSUN5 is located on B mid, the copies of NSUN5 on the other B blocks (NSUN5B and $-C)$ are transcribed as truncated copies with a shorter ORF [120]. All three NSUN5 genes are ubiquitously expressed, but with some tissue specific pattern for the truncated copies. At the present, the role of the 
NSUN5 gene product in the human organism is unclear. NSUN5 shows similarity to a $120-\mathrm{kDa}$ proliferation-associated nuclear antigen, a member of the evolutionary conserved NOL1/Nop2/sun protein family, and to other proteins with a RNA methyltransferase activity $[69,70]$.

The TRIM50 gene in B mid and its copies on B cen (TRIM74) and on B tel (TRIM73) are all expressed. They share five orthologous exons; exon 6 and 7 are only present in TRIM50 in B mid. The murine Trim50 gene encodes an E3-ubiquitin-ligase and has a putative role in the ubiquitin-mediated proteasome pathway [139].

The ancestral gene of FKBP 6 is located on B mid; the pseudogenes on $B$ cen and $B$ tel are truncated copies harbouring the first four exons of the ancestral gene $[73,57]$. FKBP6 is a component of the synaptonemal complex involved in pairing and recombination of homologous chromosomes during meiosis [57]. It plays a role in spermatogenesis; male knock out mice for FKBP6 show azoospermia, whereas in female knock out mice no apparent abnormalities are detectable [140, 141] (Fig. 2, Table 1).

\section{The single copy gene part of the WBS region}

To date 22 genes have been mapped within the single copy region of WBS between the LCR blocks C mid and B mid. So far, a genotype-phenotype correlation could be established for only a few genes (Table 1 and Fig. 2).

FZD9. The FZD9 gene codes for a transmembrane cell surface receptor, which mediates signalling upon binding to a family of secreted Wnt (Wnt: composed of $w g$ gene from drosophila melanogaster and the murine Int-1 gene) ligands. It results in the alteration of $\beta$-catenin pathway, which is known to be involved in development, tumorigenesis and stem cell self-renewal. Fzd9 knock out mice exhibit some neuroanatomical defects in hippocampus development (high numbers of apoptotic cells and reduction in the total number of granule cells). Functionally, they displayed a higher seizure predisposition and defects in visuospatial learning tasks [142]. In another study on $F z d 9$ knock out mice, no developmental/morphologic features typical for WBS were observed. The symptoms of homozygous knock out mice were limited to the hematopoietic system with a decrease of B cells in the bone marrow. Individuals with WBS, who display heterozygous loss of the FZD9 gene, usually do not develop any abnormalities in the immunologic or hematopoietic system [143].
BAZ1B. The BAZ1B protein (alias WSTF: Williams syndrome transcription factor) is a component of ATP-dependent chromatin remodelling complexes WINAC (WSTF Including Nucleosome Assembly Complex); these complexes are required in many nuclear processes such as replication, transcription and chromatin maintenance [144-146]. Furthermore, the WINAC complex interacts with the vitamin D receptor via ligand-induced transactivation of the receptor [147]. $B A Z 1 B$ is expressed differentially in neural tissue and it is subcellularly localized to condensed chromatin. Haploinsufficiency of this gene possibly leads to an increased chromosomal condensation and an overall impaired transcriptional activity of cells, leading to diverse abnormalities, including abnormal vitamin D metabolism and hypercalcaemia [144-147].

BCL7B. The function of this gene remains unclear. It shows a high similarity to $B C L 7 A$ on chromosome 12 and $B C L 7 C$ on chromosome 8 . These genes are distributed in the cytoplasm and are expressed in early embryonic development. For BCL7A, a contribution to the development of non-Hodgkin-lymphoma has been shown [148]. However, for BCL7B and -C such a role has not been demonstrated $[53,74]$.

TBL2. This gene was identified as a protein of the $\beta$ transducin family with four putative WD40-domains $[59,74]$. Expression was shown ubiquitously at lower levels but predominantly with a smaller transcript in testis, skeletal muscle, heart and some endocrine tissues [59]. The function of TBL2 is not resolved so far. There are some references that transducin family related proteins act as tumour suppressors $[149,150]$.

MLXIPL. This gene with alias names: $C H R E B P$ or WBSCR14 encodes a basic-helix-loop-helix leucine zipper (bHLHZip) transcription factor of the Mondo family and is expressed in multiple tissues [74, 151]. It binds to a carbohydrate response element in the promoter of some glucose-regulated and lipogenic genes and activates their expression [152-154].

VPS37D. The function of VPS37D (alias WBSCR24) has not been characterised so far. Orthologous genes of VPS37D are part of the ESCRT-I (endosomal sorting complex required for transport). This protein complex functions in recognition and sorting of ubiquitinated transmembrane proteins into multivesicular body vesicles. In human, four homologous proteins (VPS37A-D) have been identified [155157]. 
DNAJC30. DNAJC30 (WBSCR18) is a member of the DNAJ molecular chaperone homology domaincontaining protein family [70]. This is a super family of heat shock proteins (HSPs), known to stimulate the ATPase domain of HSPA chaperones. In the human genome, at least 41 different DNAJ-encoding genes have been identified; the cellular functions are currently unknown for most of its members [158].

WBSCR22. The putative protein of the WBSCR22 gene contains an S-adenosyl-L-methionine binding motif typical of methyltransferases. Expression was detected ubiquitously with a strong signal in testis [69, 70].

STX1A. STX1A plays an essential role in exocytosis of neuronal and neuroendocrine cells; it is also related to neurotransmitter release and vesicle fusion processes. Furthermore, it is suggested that STX1A directly modulates ion channels in exocrine and muscular cells [47, 159-162]. Both Stxla knock out - and Stx1a transgenic mice display a reduced insulin release and an impaired glucose homeostasis, possibly via an aberrant regulation of pancreatic $\beta$-cell ion channels. The genetic alteration of STX1A levels might also contribute to impaired glucose metabolism, which occurs with increased incidence in adults with WBS [23, 163, 164]. In cognitive functional test, Stx1a knock out mice demonstrated an increased conditioned fear memory lacking any other difference in appearance compared with control littermate [165].

ABHD11. $A B H D 11$ (WBSCR21) contains an $\alpha-\beta$ hydrolase domain. It is spliced in different transcripts; some of them are truncated. The gene is expressed ubiquitously, the biological function has not been determined so far [70].

CLDN3 and CLDN4. The claudin (CLDN) genes encode a family of proteins involved in the formation and function of tight junctions, and they are implicated in regulating the permeability of the paracellular pathway. The expression of the CLDN genes is frequently altered in several human cancers [166168].

WBSCR27 and WBSCR28. The function of these genes remains unclear. Recently, in a study of genes which are involved in the development of prostate cancer, WBSCR28 was repressed by androgen receptor activity [169].

ELN. The elastin gene is the best-explored gene of the WBS region and it has been demonstrated that haploinsufficiency as well as heterozygous point mutations cause SVAS [29-34, 170]. Heterozygous knock out mice of the Eln gene display high blood pressure, constriction of arteries and rigid arterial walls [170].

LIMK1. This gene belongs to a protein kinase family involved in brain development. It has been shown invivo that LIMK1 is localized at the neuromuscular synapse, suggesting that LIMK1 may play a role in synapse formation and maintenance [171]. A striking feature in children with WBS is the disability of reproduction of visually obtained objects (impaired visuospatial constructive cognition), LIMK1 is suspected to contribute to this characteristic. This assumption is based on reports of children, affected by an isolated SVAS and a visuospatial impairment, with a partial deletion of the WBS region comprising only the genes $E L N$ and $L I M K 1$ [43,172]. In contrast to these facts, other reports on individuals with partial deletion of the WBS region encompassing the LIMK1 region do not display weakness in spatial cognition [44, 173]. Limk1 knock out mice display insufficiency in re-learning spatial information. Furthermore, they show abnormalities in synaptic structure and dendritic spine development, most likely due to aberrant quantitative and structural regulation of the actin cytoskeleton [174]. In summary, these data support the assumption that LIMK1 contributes in larger scale to brain morphology (i.e. synaptic structure and -plasticity) and cognitive function (i.e. impaired spatial cognition and abnormal motor activity). However, it remains unclear if these abnormalities in dendritic spine morphology are also present in WBS patients and contribute to the morphological and behavioural abnormalities observed.

EIF4H. This gene is ubiquitously expressed and it is suggested that it is involved in translation initiation and in stabilizing attributes during RNA binding, ATP hydrolysis and RNA duplex unwinding [175].

LAT2. LAT2 is a transmembrane adaptor in specific cell types of hematopoietic lineages. Functional studies have indicated that LAT2 plays a putative role as regulator of mast cell activation, but its defined role in the organism remains unclear [176].

RFC2. RFC2 is a subunit of the replication factor C complex that, together with the proliferating-cell nuclear antigen (PCNA), is required for elongation of primed DNA templates [45]. When bound to DNA, this complex organizes various proteins involved in DNA replication, DNA repair, DNA modification and chromatin modelling [177]. 
CLIP2. CLIP2 (alias CYLN2) belongs to a family of membrane-microtubule interacting proteins that is highly enriched in neurons of the hippocampus, piriform cortex, olfactory bulb, and inferior olive [56]. Clip2 knock out mice show both morphological brain abnormalities and behavioural abnormalities that can be attributed to deficits in cerebellar and hippocampal functioning [178]. Furthermore, there are several reports of partial deletions of the WBS region not including the CLIP2 gene. The clinical findings in this collective suggest a major role for CLIP2 in the motor and cognitive characteristics of WBS. These patients with a partial deletion excluding, amongst others, the CLIP2 gene displayed only a mild or no visual-spatial impairment and they performed better on tasks testing perception, fine motor coordination and gross motor skills $[178,179]$.

GTF2IRD1. GTF2IRD1 belongs, together with GTF2I and GTF2IRD2 (located in LCR block B), to the TFIII transcription factor family, the gene products are involved in transcriptional regulation, signal transduction, immune response and chromatin remodelling. Functional studies on GTF2IRD1 in different species have shown that it binds to a number of regulatory elements upstream of genes, which are involved in tissue development and differentiation [180]. Expression of Gtf2ird1 during mouse development is found predominantly in musculoskeletal tissues, the pituitary, craniofacial tissues, the eyes and tooth buds [181]. In addition, the TFII-I gene family shows high expression during murine odontogenesis, expression of Gtf2irdl and Gtf2ird2 was observed in preameloblasts and preodontoblasts. So maybe, haploinsufficiency of these genes is causative for tooth abnormalities in WBS [182, 183]. Homozygous knock out mice of Gtf2ird1 display further craniofacial abnormalities including periorbital fullness and a short snout related to those craniofacial dysmorphisms seen in WBS. This is consistent with the expression pattern of Gtf2ird1 in the development of the brain and craniofacial areas. Furthermore, this conclusion is supported by the function of GTF2IRD1 to regulate expression of genes, which are involved in craniofacial and skeletal development [184]. Furthermore, mutant mice reveal reduced fear and aggression and increased social behaviour, which would be in accord with the typical findings of hypersociability in WBS. Biochemical analyses showed an increased serotonin metabolism in several brain regions [185]. However, in another study on Gtf2irdl knock out mice no morphological abnormalities of the brain (except of increased ventricle volume) and in hippocampal and cerebellar functioning (i.e. fear conditioning and motor coordination tests) were observed in the mice mutants [179].
WBSCR23. WBSCR23 is a putative intronless gene of $\sim 800$ bp mapped to intron 9 of the GTF2IRD1 gene with the same orientation as GTF2IRD1. The function of this transcript remains still unclear.

\section{Expression level of genes within the WBS region}

There are some studies that have investigated the expression level of WBS genes in different genomic rearrangements of the WBS region. In a collection of WBS patients with a common deletion size, the expression of genes located within the WBS region (including LCR blocks) and some genes located outside the WBS region was studied by quantitative real time PCR. With the exception of two genes (ELN and GTF2IRD1), hemizygously deleted genes within the WBS region showed significantly reduced expression levels that were approximately $50 \%$ of the wild type levels. The origin of the aberrant expression level of ELN and GTF2IRD1 could not be studied in more detail due to restricted sample number and suspected tissue specific expression pattern of both genes. In addition, a remarkable decrease in relative expression was also detected in non-hemizygous genes outside the WBS deletion region (ASL, KCTD7, HIP1, POR, $M D H 2)$, though the expression decrease was not as large as that observed for hemizygous genes. These findings suggest that genes that map close to the deletion region may be regulated by genes located within the WBS region via cis-regulatory elements and are jointly responsible for features of WBS phenotype [186].

An altered expression of genes within the WBS region was also found in patients with duplications in this region. Gene-expression analysis for GTF2I, LIMK1, $E I F 4 H, R F C 2, B A Z 1 B$ and LAT2 revealed an increased expression for all tested genes except of $L A T 2$. The expression of $L A T 2$ showed normal level that was consistent with levels in controls. In persons with a WBS, the expression level of $L A T 2$ is reduced. For WBSCR16 located outside to the telomeric breakpoint no altered expression was seen [112].

In individuals carrying an inversion of WBS region, no significant differences in gene expression were found compared to a collection without the inversion [108].

\section{Genotype-Phenotype correlation in WBS}

The WBS deletion region encompasses to date 28 transcribed genes. The design of a genotype-phenotype correlation in patients with WBS is difficult due to some special patterns concerning the WBS region. Currently, data of altered expression and haploinsufficiency in 
affected genes are only available on a restricted number of loci. Furthermore, the benefit from knock out mice concerning mental and behavioural aspects in WBS is limited, especially for the development of the cognitive features in WBS, in which a co-action of several genes is proposed. The minimal critical interval that causes the typical phenotype in individuals with WBS is estimated to span the region between the ELN gene and the common telomeric breakpoint $[112,127]$. Undoubtedly, haploinsufficiency of the ELN gene causes SVAS and other cardiovascular manifestations; further, it might contribute to connective tissue weakness (i.e. inguinal hernia) [187]. For the occurrence of the behavioural and the cognitive aspects in WBS patients (mental retardation, visual spatial impairment, overfriendliness and strength in verbal skills), several genes telomeric to the ELN gene are suspected of being responsible. Based on results from knock out mice studies, from in vitro assays on gene expression and from clinical findings in patients with only partial deletions of the WBS region, the genes LIMK1, CLIP2 (alias CYLN2) and the two members of TFII-I transcription family (GTF2IRD1 and GTF2I) are identified as playing the major role in developing the cognitive features [12, 43, 93-95, 179, 186, 188]. Furthermore there are some hints that haploinsufficiency of $B A Z 1 B$ may contribute to the hypercalcaemia in infants with WBS [147].

\section{Diagnosis and genetic counselling in WBS}

The diagnosis of WBS should be considered if typical symptoms such as SVAS together with mental retardation and other typical behavioural features occur in a patient. FISH analysis can be performed to confirm diagnosis. The FISH- and/or microsatellite analyses are the most widespread analysis strategies for deletion detection in WBS patients [40]. These analyses are useful tools for routine diagnosis of WBS and allow an approximate estimation of the deletion size. To establish a phenotype/genotype correlation and for prediction of disease-course and development depending on the number of deleted genes, a quantitative assay for diagnosis is more appropriate. The quantitative realtime PCR (qPCR) or MLPA assay ${ }^{\circledR}$ (multiplex ligationdependent probe amplification) are currently the most useful methods $[189,190]$. With the quantitative assays, a high resolution of the deletion size is possible as compared to conventional techniques, i.e. FISH or microsatellite investigations. Moreover, informative STS markers and parental DNA for microsatellite analysis are not necessary. Furthermore, qPCR allows subsequent analysis of the sub regions of microdeletions and allows refining the deletion breakpoints. At present, the quantitative determination of deletion size is restricted to research applications, since the clinical benefit is limited by the lack of strong correlation between deletion size and phenotype. One exception may be the NCF1 gene, where, in the case of nonhemizygousity, the development of hypertension is more likely [136]. Furthermore, the detection of much larger deletions expanding the common deletion size of the region may have significant prognostic value, since these patients seem to suffer from a more severe course of disease and often present with seizure [68,191-194]. Usually, WBS occurs sporadically with only a slight increased risk in the range of $1-2 \%$ of recurrences for siblings of affected children. Nevertheless, the possibility of a gonadal mosaicism for the deletion has to be considered [79, 80]. Inversion carriers at 7q11.23 will have an increased risk of meiotic recombination leading to gametes with unbalanced rearrangements. In the chromosomal region of WBS, a recombination rate of $0.3-1 \%$ approximately matches to the genome average of $1 \mathrm{Mb}$. Therefore, the frequency of recombination in the misaligned non-inverted fragments $(\sim 100$ $\mathrm{kb}$ ) would be $0.03-0.1 \%$, leading to a deletion and or duplication $[103,106]$. In addition, in case of a paracentric inversion the formation of either one or two chromosomal loops can arise. If recombination occurs within the loops it would lead to either an acentric or dicentric chromosome 7 , which would be associated with an increased risk for abortion in families carrying the inversion polymorphism. For carriers of either two or four flanking LCR blocks as a replacement for the normal three LCR copies (5\% of the WBS-transmitting progenitors) a further predisposition for unequal chromosomal misalignment exists [78, 106, 128].

Acknowledgments. The author would like to thank Dr. B. Zoll and Dr. P. Burfeind for discussion and critical assessment of the manuscript. The work was funded by the Institute for Human Genetics in Goettingen, Germany.

Electronic-Database Information

Literature and molecular databases used from the National Center for Biotechnology Information, Build 36.3, March 2008:

http://www.ncbi.nlm.nih.gov/sites/entrez?db=PubMed; http://www.ncbi.nlm.nih.gov/sites/entrez?db=OMIM\&itool=toolbar:

http://www.ncbi.nlm.nih.gov/sites/entrez?db=gene;

http://blast.ncbi.nlm.nih.gov/Blast.cgi;

Molecular databases and electronic tools used from the UCSC Genome Browser database, assembly March 2006:

http://genome.ucsc.edu/cgi-bin/hgGateway; http://genome.ucsc.edu/cgi-bin/hgBlat ?command= start\&org=Human \&db=hg18\&hgsid $=109429202$; http://genome.ucsc.edu/cgi-bin/hgPcr?org= Human \&db=hg18\&hgsid $=109429202$; 
Nomenclature of genes presented herein: HUGO Gene, Nomenclature Committee: http://www.genenames.org/

1 Strømme, P., Bjørnstad, P. G. and Ramstad, K. (2002) Prevalence estimation of Williams syndrome. J. Child. Neurol.17, 269-271.

2 Fanconi, G., Girardet, P., Schlesinger, B., Butler, N. and Black, J. (1952) [Chronic hyperglycemia, combined with osteosclerosis, hyperazotemia, nanism and congenital malformations.] Helv. Paediatr. Acta. 7, 314-349.

3 Lightwood, R. and Stapleton, T. (1953) Idiopathic hypercalcaemia in infants. Lancet 265, 255-256.

4 Jones, K. L. (1990) Williams syndrome: an historical perspective of its evolution, natural history, and etiology. Am. J. Med. Genet. 6, Suppl. 89-96.

5 Williams, J. C,, Barratt-Boyes, B. G. and Lowe, J. B. (1961) Supravalvular aortic stenosis. Circulation 24, 1311-1318.

6 Beuren, A. J., Apitz, J. and Harmjanz, D. (1962) Supravalvular aortic stenosis in association with mental retardation and a certain facial appearance. Circulation 26, 1235-1240.

7 Partsch, C. J., Dreyer, G., Gosch, A., Winter, M., Schneppenheim, R., Wessel, A. and Pankau, R. (1999) Longitudinal evaluation of growth, puberty, and bone maturation in children with Williams syndrome. J. Pediatr. 1, 82-89.

8 Burn, J. (1986) Williams syndrome. J. Med. Genet. 23, 389395.

9 Bellugi, U., Bihrle, A., Jernigan, T., Trauner, D. and Doherty, S. (1990) Neuropsychological, neurological, and neuroanatomical profile of Williams syndrome. Am. J. Med. Genet. 6 , Suppl. 115-125.

10 Bellugi, U., Adolphs, R., Cassady, C. and Chiles, M. (1999) Towards the neural basis for hypersociability in a genetic syndrome. Neuroreport 10, 1653-1657.

11 Jones, W., Bellugi, U., Lai, Z., Chiles, M., Reilly, J., Lincoln, A. and Adolphs, R. (2000) II. Hypersociability in Williams Syndrome. J. Cogn. Neurosci. 12, Suppl. 30-46.

12 Francke, U. (1999) Williams-Beuren syndrome: genes and mechanisms. Hum. Mol. Genet. 8, 1947-1954.

13 Davies, M., Udwin, O. and Howlin, P. (1998) Adults with Williams syndrome. Preliminary study of social, emotional and behavioural difficulties. Br. J. Psychiatry 172, 273-276.

14 Gosch, A. and Pankau, R. (1997) Personality characteristics and behaviour problems in individuals of different ages with Williams syndrome. Dev. Med. Child. Neurol. 39, 527-533.

15 Mervis, C. B. and Klein-Tasman, B. P. (2000) Williams syndrome: cognition, personality, and adaptive behavior. Ment. Retard. Dev. Disabil. Res. Rev. 6, 148-158.

16 Morris, C. A., Demsey, S. A., Leonard, C. O., Dilts, C. and Blackburn, B. L. (1988) Natural history of Williams syndrome: physical characteristics. J. Pediatr. 113, 318-326.

17 Brinkmann, G., Heller, M., Partsch, C. J., Gosch, A. and Pankau, R. (1997) Magnetic resonance imaging of the brain in Williams-Beuren syndrome. Am. J. Med. Genet. 68, 243.

18 Schmitt, J. E., Eliezm S., Bellugi, U. and Reiss, A.L. (2001) Analysis of cerebral shape in Williams syndrome. Arch. Neurol. 58, 283-287.

19 Kruse, K., Pankau, R., Gosch, A. and Wohlfahrt, K. (1992) Calcium metabolism in Williams-Beuren syndrome. J. Pediatr. 121, 902-907.

20 Kaplan, P., Kirschner, M., Watters, G. and Costa, M. T. (1989) Contractures in patients with Williams syndrome. Pediatrics 84, 895-899.

21 Castorina, P., Selicorni, A., Bedeschi, F., Dalprà, L. and Larizza, L. (1997) Genotype-phenotype correlation in two sets of monozygotic twins with Williams syndrome. Am. J. Med. Genet. 69, 107-111.

22 Cambiaso, P., Orazi, C., Digilio, M. C., Loche, S., Capolino, R., Tozzi, A., Faedda, A. and Cappa, M. (2007) Thyroid morphology and subclinical hypothyroidism in children and adolescents with Williams syndrome. J. Pediatr. 150, 62-65.
23 Cherniske, E. M., Carpenter, T. O., Klaiman, C., Young, E., Bregman, J., Insogna, K., Schultz, R. T. and Pober, B. R. (2004) Multisystem study of 20 older adults with Williams syndrome. Am. J. Med. Genet. A. 131, 255-264.

24 Leyfer, O. T., Woodruff-Borden, J., Klein-Tasman, B. P., Fricke, J. S. and Mervis, C. B. (2006) Prevalence of psychiatric disorders in 4 to 16 -year-olds with Williams syndrome. Am. J. Med. Genet. B. Neuropsychiatr. Genet. 141, 615-622.

25 Davies, M., Howlin, P. and Udwin, O. (1997) Independence and adaptive behavior in adults with Williams syndrome. Am. J. Med. Genet. 70, 188-195.

26 Menko, F. H. and Stouthart, P. J. (1992) Williams syndrome and chromosome 18. J. Med. Genet. 29, 679-680.

27 Tupler, R., Maraschio, P., Gerardo, A., Mainieri, R., Lanzi, G. and Tiepolo, L. (1992) A complex chromosome rearrangement with 10 breakpoints: tentative assignment of the locus for Williams syndrome to 4q33-q35.1. J. Med. Genet. 29, 253-255.

28 Colley, A., Thakker, Y., Ward, H. and Donnai, D. (1992) Unbalanced 13;18 translocation and Williams syndrome. J. Med. Genet. 29, 63-65.

29 Morris, C. A., Loker, J., Ensing, G. and Stock, A. D. (1993) Supravalvular aortic stenosis cosegregates with a familial 6;7 translocation which disrupts the elastin gene. Am. J. Med. Genet. 46, 737-744.

30 Fazio, M. J., Mattei, M. G., Passage, E., Chu, M. L., Black, D., Solomon, E., Davidson, J. M. and Uitto, J. (1991) Human elastin gene: new evidence for localization to the long arm of chromosome 7. Am. J. Hum. Genet. 48, 696-703.

31 Olson, T. M., Michels, V. V., Lindor, N. M., Pastores, G. M., Weber, J. L., Schaid, D. J., Driscoll, D. J., Feldt, R. H. and Thibodeau, S. N. (1993) Autosomal dominant supravalvular aortic stenosis: localization to chromosome 7. Hum. Mol. Genet. 2, 869-873.

32 Curran, M. E., Atkinson, D. L., Ewart, A. K., Morris, C. A., Leppert, M. F. and Keating, M. T. (1993) The elastin gene is disrupted by a translocation associated with supravalvular aortic stenosis. Cell 73, 159-168.

33 Ewart, A. K., Morris, C. A., Atkinson, D., Jin, W., Sternes, K., Spallone, P., Stock, A. D., Leppert, M. and Keating, M. T. (1993) Hemizygosity at the elastin locus in a developmental disorder, Williams syndrome. Nat. Genet. 5, 11-16.

34 Tassabehji, M., Metcalfe, K., Donnai, D., Hurst, J., Reardon, W., Burch, M. and Read, A. P. (1997) Elastin: genomic structure and point mutations in patients with supravalvular aortic stenosis. Hum. Mol. Genet. 6, 1029-1036.

35 Ewart, A. K., Morris, C. A., Ensing, G. J., Loker, J., Moore, C., Leppert, M. and Keating, M. (1993) A human vascular disorder, supravalvular aortic stenosis, maps to chromosome 7. Proc. Natl. Acad. Sci. USA. 90, 3226-3230.

36 Lowery, M. C., Morris, C. A., Ewart, A., Brothman, L. J., Zhu, X. L., Leonard, C. O., Carey, J. C., Keating, M. and Brothman, A. R. (1995) Strong correlation of elastin deletions, detected by FISH, with Williams syndrome: evaluation of 235 patients. Am. J. Hum. Genet. 57, 49-53.

37 Nickerson, E., Greenberg, F., Keating, M. T., McCaskill, C. and Shaffer, L. G. (1995) Deletions of the elastin gene at $7 \mathrm{q} 11.23$ occur in approximately $90 \%$ of patients with Williams syndrome. Am. J. Hum. Genet. 56, 1156-1161.

38 Borg, I., Delhanty, J. D. and Baraitser, M. (1995) Detection of hemizygosity at the elastin locus by FISH analysis as a diagnostic test in both classical and atypical cases of Williams syndrome. J. Med. Genet. 32, 692-696.

39 Mari, A., Amati, F., Mingarelli, R., Giannotti, A., Sebastio, G., Colloridi, V., Novelli, G. and Dallapiccola, B. (1995) Analysis of the elastin gene in 60 patients with clinical diagnosis of Williams syndrome. Hum. Genet. 96, 444-448

40 Brøndum-Nielsen, K., Beck, B., Gyftodimou, J., Hørlyk, H., Liljenberg, U., Petersen, M.B., Pedersen, W., Petersen, M. B., Sand, A., Skovby, F., Stafanger, G., Zetterqvist, P. and Tommerup, N. (1997) Investigation of deletions at 7q11.23 
in 44 patients referred for Williams-Beuren syndrome, using FISH and four DNA polymorphisms. Hum. Genet. 99, 56-61.

41 Gilbert-Dussardier, B., Bonneau, D., Gigarel, N., Le Merrer, M., Bonnet, D., Philip, N., Serville, F., Verloes, A., Rossi, A., Aymék, S., Weissenbach, J., Mattei, M. G., Lyonnet, S. and Munnich, A. (1995) A novel microsatellite DNA marker at locus D7S1870 detects hemizygosity in $75 \%$ of patients with Williams syndrome. Am. J. Hum. Genet. 56, 542-544.

42 Robinson, W. P., Waslynka, J., Bernasconi, F., Wang, M., Clark, S., Kotzot, D. and Schinzel, A. (1996) Delineation of $7 \mathrm{q} 11.2$ deletions associated with Williams-Beuren syndrome and mapping of a repetitive sequence to within and to either side of the common deletion. Genomics 34, 17-23.

43 Frangiskakis, J. M., Ewart, A. K., Morris, C. A., Mervis, C. B., Bertrand, J., Robinson, B. F., Klein, B. P., Ensing, G. J., Everett, L. A., Green, E. D., Proschel, C., Gutowski, N. J., Noble, M., Atkinson, D. L., Odelberg, S. J. and Keating, M. T. (1996) LIM-kinase1 hemizygosity implicated in impaired visuospatial constructive cognition. Cell 86, 59-69.

44 Tassabehji, M., Metcalfe, K., Fergusson, W. D., Carette, M. J., Dore, J. K., Donnai, D., Read, A. P., Pröschel, C., Gutowski, N. J., Mao, X. and Sheer, D. (1996) LIM-kinase deleted in Williams syndrome. Nat. Genet. 13, 272-273.

45 Peoples, R., Perez-Jurado, L., Wang, Y. K., Kaplan, P. and Francke, U. (1996) The gene for replication factor C subunit 2 (RFC2) is within the 7q11.23 Williams syndrome deletion. Am. J. Hum. Genet. 58, 1370-1373.

46 Osborne, L. R., Martindale, D., Scherer, S. W., Shi, X. M., Huizenga, J., Heng, H. H., Costa, T., Pober, B., Lew, L., Brinkman, J., Rommens, J., Koop, B. and Tsui, L. C. (1996) Identification of genes from a $500-\mathrm{kb}$ region at $7 \mathrm{q} 11.23$ that is commonly deleted in Williams syndrome patients. Genomics $36,328-336$.

47 Osborne, L. R., Soder, S., Shi, X. M., Pober, B., Costa, T., Scherer, S. W. and Tsui, L. C. (1997) Hemizygous deletion of the syntaxin $1 \mathrm{~A}$ gene in individuals with Williams syndrome. Am. J. Hum. Genet. 61, 449-452.

48 Osborne, L. R., Herbrick, J. A., Greavette, T., Heng, H. H., Tsui, L. C. and Scherer, S. W. (1997) PMS2-related genes flank the rearrangement breakpoints associated with Williams syndrome and other diseases on human chromosome 7. Genomics 45, 402-406.

49 Wang, Y. K., Samos, C. H., Peoples, R., Pérez-Jurado, L. A., Nusse, R. and Francke, U. (1997) A novel human homologue of the Drosophila frizzled wnt receptor gene binds wingless protein and is in the Williams syndrome deletion at 7q11.23. Hum. Mol. Genet. 6, 465-472.

$50 \mathrm{Lu}$, X., Meng, X., Morris, C. A. and Keating, M. T. (1998) A novel human gene, WSTF, is deleted in Williams syndrome. Genomics 54, 241-249.

51 Peoples, R. J., Cisco, M. J., Kaplan, P. and Francke, U. (1998) Identification of the WBSCR9 gene, encode a novel transcriptional regulator, in the Williams-Beuren syndrome deletion at 7q11.23. Cytogenet. Cell Genet. 82, 238-246.

52 Paperna, T., Peoples, R., Wang, Y. K., Kaplan, P. and Francke, U. (1998) Genes for the CPE receptor (CPETR1) and the human homolog of RVP1 (CPETR2) are localized within the Williams-Beuren syndrome deletion. Genomics 54, 453-459.

53 Jadayel, D. M., Osborne, L. R., Coignet, L. J., Zani, V. J., Tsui, L. C., Scherer, S. W. and Dyer, M. J. (1998) The BCL7 gene family: deletion of BCL7B in Williams syndrome. Gene 224, $35-44$.

54 Osborne, L. R., Campbell, T., Daradich, A., Scherer, S. W. and Tsui, L. C. (1999) Identification of a putative transcription factor gene (WBSCR11) that is commonly deleted in Williams-Beuren syndrome. Genomics 57, 279-284.

55 Nakayama, T., Matsuoka, R., Kimura, M., Hirota, H., Mikoshiba, K., Shimizu, Y., Shimizu, N. and Akagawa, K. (1998) Hemizygous deletion of the HPC-1/syntaxin 1A gene (STX1A) in patients with Williams syndrome. Cytogenet. Cell Genet. 82, 49-51.
56 Hoogenraad, C. C., Eussen, B. H., Langeveld, A., van Haperen, R., Winterberg, S., Wouters, C. H., Grosveld, F., De Zeeuw, C. I. and Galjart, N. (1998) The murine CYLN2 gene: genomic organization, chromosome localization, and comparison to the human gene that is located within the 7q11.23 Williams syndrome critical region. Genomics 53, 348-358.

57 Meng, X., Lu, X., Morris, C. A. and Keating, M. T. (1998) A novel human gene FKBP6 is deleted in Williams syndrome. Genomics 52, 130-137.

58 Wang, Y. K., Spörle, R., Paperna, T., Schughart, K. and Francke, U. (1999) Characterization and expression pattern of the frizzled gene Fzd9, the mouse homolog of FZD9 which is deleted in Williams-Beuren syndrome. Genomics 57, 235248.

59 Perez Jurado, L. A., Wang, Y. K., Francke, U. and Cruces, J. (1999) TBL2, a novel transducin family member in the WBS deletion: characterization of the complete sequence, genomic structure, transcriptional variants and the mouse ortholog. Cytogenet. Cell Genet. 86, 277-284.

60 Pérez Jurado, L. A., Wang, Y. K., Peoples, R., Coloma, A., Cruces, J. and Francke, U. (1998) A duplicated gene in the breakpoint regions of the 7q11.23 Williams-Beuren syndrome deletion encodes the initiator binding protein TFII-I and BAP-135, a phosphorylation target of BTK. Hum. Mol. Genet. 7, 325-334.

61 Wang, Y. K., Pérez-Jurado, L. A. and Francke, U. (1998) A mouse single-copy gene, Gtf2i, the homolog of human GTF2I, that is duplicated in the Williams-Beuren syndrome deletion region. Genomics 48, 163-170.

62 Wu, Y. Q., Sutton, V. R., Nickerson, E., Lupski, J. R., Potocki, L., Korenberg, J. R., Greenberg, F., Tassabehji, M. and Shaffer, L. G. (1998) Delineation of the common critical region in Williams syndrome and clinical correlation of growth, heart defects, ethnicity, and parental origin. Am. J. Med. Genet. 78, 82-89.

63 Nicolaides, N. C., Carter, K. C., Shell, B. K., Papadopoulos, N., Vogelstein, B. and Kinzler, K. W. (1995) Genomic organization of the human PMS2 gene family. Genomics 30, 195-206.

64 Tassabehji, M., Carette, M., Wilmot, C., Donnai, D., Read, A. P. and Metcalfe, K. (1999) A transcription factor involved in skeletal muscle gene expression is deleted in patients with Williams syndrome. Eur. J. Hum. Genet. 7, 737-747.

65 Franke, Y., Peoples, R. J. and Francke, U. (1999) Identification of GTF2IRD1, a putative transcription factor within the Williams-Beuren syndrome deletion at 7q11.23. Cytogenet. Cell Genet. 86, 296-304.

66 Tipney, H. J., Hinsley, T. A., Brass, A., Metcalfe, K., Donnai, D. and Tassabehji, M. (2004) Isolation and characterisation of GTF2IRD2, a novel fusion gene and member of the TFII-I family of transcription factors, deleted in Williams-Beuren syndrome. Eur. J. Hum. Genet. 12, 551-560

67 Makeyev, A. V., Erdenechimeg, L., Mungunsukh, O., Roth, J. J., Enkhmandakh, B., Ruddle, F. H. and Bayarsaihan, D. (2004) GTF2IRD2 is located in the Williams-Beuren syndrome critical region $7 \mathrm{q} 11.23$ and encodes a protein with two TFII-I-like helix-loop-helix repeats. Proc. Natl. Acad. Sci. USA. 101, 11052-11057.

68 Stock, A. D., Spallone, P. A., Dennis, T. R., Netski, D., Morris, C. A., Mervis, C. B. and Hobart, H. H. (2003) Heat shock protein 27 gene: chromosomal and molecular location and relationship to Williams syndrome. Am. J. Med. Genet. A. $120,320-325$.

69 Doll, A. and Grzeschik, K. H. (2001) Characterization of two novel genes, WBSCR20 and WBSCR22, deleted in WilliamsBeuren syndrome. Cytogenet. Cell Genet. 95, 20-27.

70 Merla, G., Ucla, C., Guipponi, M. and Reymond, A. (2002) Identification of additional transcripts in the WilliamsBeuren syndrome critical region. Hum. Genet. 110, 429-438.

71 De Luis, O., Valero, M. C. and Jurado, L. A. (2000) WBSCR14, a putative transcription factor gene deleted in 
Williams-Beuren syndrome: complete characterisation of the human gene and the mouse ortholog. Eur. J. Hum. Genet. 8, 215-222.

72 Perez Jurado, L. A., Peoples, R., Kaplan, P., Hamel, B. C. and Francke, U. (1996) Molecular definition of the chromosome 7 deletion in Williams syndrome and parent-of-origin effects on growth. Am. J. Hum. Genet. 59, 781-792.

73 Peoples, R., Franke, Y., Wang, Y. K., Perez-Jurado, L., Paperna, T., Cisco, M. and Francke, U. (2000) A physical map, including a BAC/PAC clone contig, of the Williams-Beuren syndrome-deletion region at 7q11.23. Am. J. Hum. Genet. 66, $47-68$.

74 Meng, X., Lu, X., Li, Z., Green, E. D., Massa, H., Trask, B. J., Morris, C. A. and Keating, M. T. (1998) Complete physical map of the common deletion region in Williams syndrome and identification and characterization of three novel genes. Hum. Genet. 103, 590-599.

75 Hockenhull, E. L., Carette, M. J., Metcalfe, K., Donnai, D. Read, A. P. and Tassabehji, M. (1999) A complete physical contig and partial transcript map of the Williams syndrome critical region. Genomics 58, 138-145.

76 DeSilva, U., Massa, H., Trask, B. J. and Green, E. D. (1999) Comparative mapping of the region of human chromosome 7 deleted in williams syndrome. Genome Res. 9, 428-436.

77 Pezzi, N., Prieto, I., Kremer, L., Perez Jurado, L. A., Valero, C., Del Mazo, J., Martinez-A, C. and Barbero, J. L. (2000) STAG3, a novel gene encoding a protein involved in meiotic chromosome pairing and location of STAG3-related genes flanking the Williams-Beuren syndrome deletion. FASEB J. $14,581-592$.

78 Bayes, M., Magano, L. F., Rivera, N., Flores, R. and Perez Jurado, L. A. (2003) Mutational mechanisms of WilliamsBeuren syndrome deletions. Am. J. Hum. Genet. 73, 131-151.

79 Dutly, F. and Schinzel, A. (1996) Unequal interchromosomal rearrangements may result in elastin gene deletions causing the Williams-Beuren syndrome. Hum. Mol. Genet. 5, 1893 1898.

80 Baumer, A., Dutly, F., Balmer, D., Riegel, M., Tukel, T., Krajewska-Walasek, M. and Schinzel, A. A. (1998) High level of unequal meiotic crossovers at the origin of the 22q11. 2 and 7q11.23 deletions. Hum. Mol. Genet. 7, 887-894.

81 Wang, M. S., Schinzel, A., Kotzot, D., Balmer, D., Casey, R. Chodirker, B. N., Gyftodimou, J., Petersen, M. B., LopezRangel, E. and Robinson, W. P. (1999) Molecular and clinical correlation study of Williams-Beuren syndrome: No evidence of molecular factors in the deletion region or imprinting affecting clinical outcome. Am. J. Med. Genet. 86, 34-43.

82 Urban, Z., Helms, C., Fekete, G., Csiszar, K., Bonnet, D. Munnich, A., Donis-Keller, H. and Boyd, C. D. (1996) 7q11.23 deletions in Williams syndrome arise as a consequence of unequal meiotic crossover. Am. J. Hum. Genet. 59, 958-962.

83 Thomas, N. S., Durkie, M., Potts, G., Sandford, R., Van Zyl, B., Youings, S., Dennis, N. R. and Jacobs, P. A. (2006) Parenta and chromosomal origins of microdeletion and duplication syndromes involving 7q11.23, 15q11-q13 and 22q11. Eur. J. Hum. Genet. 14, 831-837.

84 Metcalfe, K., Simeonov, E., Beckett, W., Donnai, D. and Tassabehii, M. (2005) Autosomal dominant inheritance of Williams-Beuren syndrome in a father and son with haploinsufficiency for FKBP6. Clin. Dysmorphol. 14, 61-65.

85 Morris, C. A., Thomas, I. T. and Greenberg, F. (1993) Williams syndrome: autosomal dominant inheritance. Am. J. Med. Genet. 47, 478-481.

86 Sadler, L. S., Robinson, L. K., Verdaasdonk, K. R. and Gingell, R. (1993) The Williams syndrome: evidence for possible autosomal dominant inheritance. Am. J. Med. Genet. 47, 468-470.

87 Kara-Mostefa, A., Raoul, O., Lyonnet, S., Amiel, J., Munnich, A., Vekemans, M., Magnier, S., Ossareh, B. and Bonnefont, J. P. (1999) Recurrent Williams-Beuren syndrome in a sibship suggestive of maternal germ-line mosaicism. Am. J. Hum. Genet. 64, 1475-1478.
88 Valero, M. C., de Luis, O., Cruces, J. and Perez Jurado, L. A. (2000) Fine-scale comparative mapping of the human 7q11.23 region and the orthologous region on mouse chromosome $5 \mathrm{G}$ : the low-copy repeats that flank the Williams-Beuren syndrome deletion arose at breakpoint sites of an evolutionary inversion(s). Genomics. 69, 1-13.

89 Korenberg, J. R., Chen, X.N., Hirota, H., Lai, Z., Bellugi, U., Burian, D., Roe, B. and Matsuoka, R. (2000) VI. Genome structure and cognitive map of Williams syndrome. J. Cogn. Neurosci. 12, Suppl. 89-107.

90 Karmiloff-Smith, A., Grant, J., Ewing, S., Carette, M. J., Metcalfe, K., Donnai, D., Read, A. P. and Tassabehji, M. (2003) Using case study comparisons to explore genotypephenotype correlations in Williams-Beuren syndrome. J. Med. Genet. 40, 136-140.

91 Gagliardi, C., Bonaglia, M. C., Selicorni, A., Borgatti, R. and Giorda, R. (2003) Unusual cognitive and behavioural profile in a Williams syndrome patient with atypical 7 q11.23 deletion. J. Med. Genet. 40, 526-530.

92 Edelmann, L., Prosnitz, A., Pardo, S., Bhatt, J., Cohen, N., Lauriat, T., Ouchanov, L., González, P. J., Manghi, E. R., Bondy, P., Esquivel, M., Monge, S., Delgado, M. F., Splendore, A., Francke, U., Burton, B. K. and McInnes, L. A. (2007) An atypical deletion of the Williams-Beuren syndrome interval implicates genes associated with defective visuospatial processing and autism. J. Med. Genet. 44, 136-143.

93 Morris, C. A., Mervis, C. B., Hobart, H. H., Gregg, R. G., Bertrand, J., Ensing, G. J., Sommer, A., Moore, C. A., Hopkin, R. J., Spallone, P. A., Keating, M. T., Osborne, L., Kimberley, K. W. and Stock, A. D. (2003) GTF2I hemizygosity implicated in mental retardation in Williams syndrome: genotype-phenotype analysis of five families with deletions in the Williams syndrome region. Am. J. Med. Genet. A. $123,45-59$.

94 Botta, A., Novelli, G., Mari, A., Novelli, A., Sabani, M., Korenberg, J., Osborne, L. R., Digilio, M. C., Giannotti, A. and Dallapiccola, B. (1999) Detection of an atypical 7q11.23 deletion in Williams syndrome patients which does not include the STX1A and FZD3 genes. J. Med. Genet. 36, $478-480$

95 Heller, R., Rauch, A., Lüttgen, S., Schröder, B. and Winterpacht, A. (2003) Partial deletion of the critical 1.5 Mb interval in Williams-Beuren syndrome. J. Med. Gen. 40, 99.

96 Scherer, S. W., Cheung, J., MacDonald, J. R., Osborne, L. R., Nakabayashi, K., Herbrick, J. A., Carson, A. R., ParkerKatiraee, L., Skaug, J., Khaja, R., Zhang, J., Hudek, A. K., Li, M., Haddad, M., Duggan, G. E. and Fernandez, B. A. (2003) Human chromosome 7: DNA sequence and biology. Science 300, 767-772.

97 Schubert, C. and Laccone, F. (2006) Williams-Beuren syndrome: determination of deletion size using quantitative realtime PCR. Int. J. Mol. Med. 18, 799-806.

98 International Human Genome Sequencing Consortium. (2001) Initial sequencing and analysis of the human genome. Nature 409, 860-921.

99 Stankiewicz, P. and Lupski, J. R. (2002) Molecular-evolutionary mechanisms for genomic disorders. Curr. Opin. Genet. Dev. 12, 312-319.

100 Waldman, A. S. and Liskay, R. M. (1988) Dependence of intrachromosomal recombination in mammalian cells on uninterrupted homology. Mol. Cell. Biol. 8, 5350-5357.

101 Inoue, K. and Lupski, J. R. (2002) Molecular mechanisms for genomic disorders. Annu. Rev. Genomics Hum. Genet. 3, 199-242.

102 Lupski, J. R. (1998) Genomic disorders: structural features of the genome can lead to DNA rearrangements and human disease traits. Trends Genet. 14, 417-422.

103 Turner, D. J., Miretti, M., Rajan, D., Fiegler, H., Carter, N. P., Blayney, M. L., Beck, S. and Hurles, M. E. (2008) Germline rates of de novo meiotic deletions and duplications causing several genomic disorders. Nat. Genet. 40, 90-95. 
104 Osborne, L. R., Li, M., Pober, B., Chitayat, D., Bodurtha, J., Mandel, A., Costa, T., Grebe, T., Cox, S., Tsui, L. C. and Scherer, S. W. (2001) A 1.5 million-base pair inversion polymorphism in families with Williams-Beuren syndrome. Nat. Genet. 29, 321-325.

105 Hobart, H. H., Gregg, R. G., Mervis, C. B., Robinson, B. F., Kimberley, K. W., Rios, C. M. and Morris, C. A. (2004) Heterozygotes for the microinversion of the Williams-Beuren syndrome region have an increased risk for affected offspring. Am. Soc.Hum. Genet. 54th Annual Meeting, Toronto, Abstr. 891.

106 Perez Jurado, A. L. (2003) Williams-Beuren syndrome: a model of recurrent genomic mutation. Horm. Res. 59, Suppl. 106-113.

107 Scherer, S. W., Gripp, K. W., Lucena, J., Nicholson, L., Bonnefont, J. P., Perez-Jurado, L. A. and Osborne, L. R. (2005) Observation of a parental inversion variant in a rare Williams-Beuren syndrome family with two affected children. Hum. Genet. 117, 383-388.

108 Tam, E., Young, E. J., Morris, C. A., Marshall, C. R., Loo, W., Scherer, S. W., Mervis, C. B. and Osborne, L. R. (2008) The common inversion of the Williams-Beuren syndrome region at 7q11.23 does not cause clinical symptoms. Am. J. Med. Genet. Part A 146, 1797-1806.

109 Torniero, C., Dalla Bernardina, B., Novara, F., Cerini, R., Bonaglia, C., Pramparo, T., Ciccone, R., Guerrini, R. and Zuffardi, O. (2008) Dysmorphic features, simplified gyral pattern and 7q11.23 duplication reciprocal to the WilliamsBeuren deletion. Eur. J. Hum. Genet. 16, 880-887.

110 Osborne, L. R. and Mervis, C. B. (2007) Rearrangements of the Williams-Beuren syndrome locus: molecular basis and implications for speech and language development. Expert Rev. Mol. Med. 13,1-16.

111 Berg, J. S., Brunetti-Pierri, N., Peters, S. U., Kang, S. H., Fong, C. T., Salamone, J., Freedenberg, D., Hannig, V. L., Prock, L. A., Miller, D. T., Raffalli, P., Harris, D. J., Erickson, R. P., Cunniff, C., Clark, G. D., Blazo, M. A., Peiffer, D. A., Gunderson, K. L., Sahoo, T., Patel, A., Lupski, J. R., Beaudet, A. L. and Cheung, S. W. (2007) Speech delay and autism spectrum behaviors are frequently associated with duplication of the 7q11.23 Williams-Beuren syndrome region. Genet. Med. 9, 427-441.

112 Somerville, M. J., Mervis, C. B., Young, E. J., Seo, E. J., del Campo, M., Bamforth, S., Peregrine, E., Loo, W., Lilley, M., Perez-Jurado, L. A., Morris, C. A., Scherer, S. W. and Osborne, L. R. (2005) Severe expressive-language delay related to duplication of the Williams-Beuren locus. N. Engl. J. Med. 353, 1694-1701.

113 Kirchhoff, M., Bisgaard, A. M., Bryndorf, T. and Gerdes, T (2008) MLPA analysis for a panel of syndromes with mental retardation reveals imbalances in $5.8 \%$ of patients with mental retardation and dysmorphic features, including duplications of the Sotos syndrome and Williams-Beuren syndrome regions. Eur. J. Med. Genet. 50, 33-42.

114 Orellana, C., Bernabeu, J., Monfort, S., Roselló, M., Oltra, S., Ferrer, I., Quiroga, R., Martínez-Garay, I. and Martínez, F. (2008) Duplication of the Williams-Beuren critical region: case report and further delineation of the phenotypic spectrum. J. Med. Genet. 45, 187-189.

115 Merritt, J. L. and Lindor, N. M. (2008) Further clinical description of duplication of Williams-Beuren region presenting with congenital glaucoma and brachycephaly. Am. J. Med. Genet. A. 146A, 1055-1058.

116 Torniero, C., Dalla Bernardina, B., Novara, F., Vetro, A., Ricca, I., Darra, F., Pramparo, T., Guerrini, R. and Zuffardi, O. (2007) Cortical dysplasia of the left temporal lobe might explain severe expressive-language delay in patients with duplication of the Williams-Beuren locus. Eur. J. Hum. Genet. 15, 62-67.

117 Depienne, C., Heron, D., Betancur, C., Benyahia, B., Trouillard, O., Bouteiller, D., Verloes, A., LeGuern, E., Leboyer, M. and Brice, A. (2007) Autism, language delay and mental retardation in a patient with 7q11 duplication. J. Med. Genet. 44, 452-458.

118 Kriek, M., White, S. J., Szuhai, K., Knijnenburg, J., van Ommen, G. J., den Dunnen, J. T. and Breuning, M. H. (2006) Copy number variation in regions flanked (or unflanked) by duplicons among patients with developmental delay and/or congenital malformations; detection of reciprocal and partial Williams-Beuren duplications. Eur. J. Hum. Genet. 14, 180189.

119 Tassabehji, M. and Donnai, D. (2006) Williams-Beuren Syndrome: more or less? Segmental duplications and deletions in the Williams-Beuren syndrome region provide new insights into language development. : Eur. J. Hum. Genet. 14, 507-508.

120 Antonell, A., de Luis, O., Domingo-Roura, X. and PerezJurado, L. A. (2005) Evolutionary mechanisms shaping the genomic structure of the Williams-Beuren syndrome chromosomal region at human 7q11.23. Genome Res. 15, 11791188.

121 DeSilva, U., Elnitski, L., Idol, J. R., Doyle, J. L., Gan, W., Thomas, J. W., Schwartz, S., Dietrich, N. L., BeckstromSternberg, S. M., McDowell, J. C., Blakesley, R. W., Bouffard, G. G., Thomas, P. J., Touchman, J. W., Miller, W. and Green, E. D. (2002) Generation and comparative analysis of approximately $3.3 \mathrm{Mb}$ of mouse genomic sequence orthologous to the region of human chromosome $7 \mathrm{q} 11.23$ implicated in Williams syndrome. Genome Res. 12, 3-15.

122 Müller, S., Finelli, P., Neusser, M. and Wienberg, J. (2004) The evolutionary history of human chromosome 7. Genomics. 84, 458-467.

123 Bailey, J. A., Yavor, A. M., Massa, H. F., Trask, B. J. and Eichler, E. E. (2001) Segmental duplications: organization and impact within the current human genome project assembly. Genome Res. 11, 1005-1017.

124 Bailey, J. A., Liu, G. and Eichler, E. E. (2003) An Alu transposition model for the origin and expansion of human segmental duplications. Am. J. Hum. Genet. 73, 823-834.

125 Houck, C. M., Rinehart, F. P. and Schmid, C. W. (1979) A ubiquitous family of repeated DNA sequences in the human genome. J. Mol. Biol. 132, 289-306.

126 Batzer, M. A. and Deininger, P. L. (2002) Alu repeats and human genomic diversity. Nat. Rev. Genet. 3, 370-379.

127 Tassabehji, M. (2003) Williams-Beuren syndrome: a challenge for genotype-phenotype correlations. Hum. Mol. Genet. 12, R229-R237

128 Cuscó, I., Corominas, R., Bayés, M., Flores, R., RiveraBrugués, N., Campuzano, V. and Pérez-Jurado, L. A. (2008) Copy number variation at the 7q11.23 segmental duplications is a susceptibility factor for the Williams-Beuren syndrome deletion. Genome Res. 18, 683-694.

129 De Vos, M., Hayward, B. E., Picton, S., Sheridan, E. and Bonthron, D. T. (2004) Novel PMS2 pseudogenes can conceal recessive mutations causing a distinctive childhood cancer syndrome. Am. J. Hum. Genet. 74, 954-964.

130 Lynch, H. T., Lynch, J. F. (1995) Clinical implications of advances in the molecular genetics of colorectal cancer. Tumori. 81, Suppl. 19-29.

131 Hinsley, T. A., Cunliffe, P., Tipney, H. J., Brass, A. and Tassabehji, M. (2004) Comparison of TFII-I gene family members deleted in Williams-Beuren syndrome. Protein Sci. 13, 2588-2599.

132 Hirota, H., Matsuoka, R., Chen, X. N., Salandanan, L. S., Lincoln, A., Rose, F. E., Sunahara, M., Osawa, M., Bellugi, U. and Korenberg, J. R. (2003) Williams syndrome deficits in visual spatial processing linked to GTF2IRD1 and GTF2I on chromosome 7q11.23. Genet. Med. 5, 311-321

133 Holinger, D. P., Bellugi, U., Korenberg, J. R., Mills, D. L., Reiss, A. L. and Galaburda, A. M. (2004) Genes, neural systems, and cognition: neuronal measures in area 39-40 of inferior parietal lobule in Williams syndrome support dorsalventral hypothesis. Society for Neuroscience Washington, DC. Program No. 666.12. 
134 Francke, U., Hsieh, C. L., Foellmer, B. E., Lomax, K. J., Malech, H. L. and Leto, T. L. (1990) Genes for two autosomal recessive forms of chronic granulomatous disease assigned to 1q25 (NCF2) and 7q11.23 (NCF1). Am. J. Hum. Genet. 47, $483-492$

135 Görlach, A., Lee, P. L., Roesler, J., Hopkins, P. J., Christensen, B., Green, E. D., Chanock, S. J. and Curnutte, J. T. (1997) A p47-phox pseudogene carries the most common mutation causing p47-phox- deficient chronic granulomatous disease. J. Clin. Invest. 100, 1907-1918.

136 Del Campo, M., Antonell, A., Magano, L. F., Munoz, F. J., Flores, R., Bayes, M. and Perez Jurado, L. A. (2006) Hemizygosity at the NCF1 gene in patients with Williams-Beuren syndrome decreases their risk of hypertension. Am. J. Hum. Genet. 78, 533-542.

137 Landmesser, U., Cai, H., Dikalov, S., McCann, L., Hwang, J., Jo, H., Holland,S. M. and Harrison, D. G. (2002) Role of p47(phox) in vascular oxidative stress and hypertension caused by angiotensin II. Hypertension. 40, 511-515.

138 Funakoshi, T., Maeshima, K., Yahata, K., Sugano, S. Imamoto, F. and Imamoto, N. (2007) Two distinct human POM121 genes: requirement for the formation of nuclear pore complexes. FEBS Lett. 581, 4910-4916.

139 Micale, L., Fusco, C., Augello, B., Napolitano, L. M., Dermitzakis, E. T., Meroni, G., Merla, G. and Reymond, A. (2008) Williams-Beuren syndrome TRIM50 encodes an E3 ubiquitin ligase. Eur. J. Hum. Genet. doi:10.1038/ejhg.2008.68

140 Crackower, M. A., Kolas, N. K., Noguchi, J., Sarao, R., Kikuchi, K., Kaneko, H., Kobayashi, E., Kawai, Y., Kozieradzki, I., Landers, R., Mo, R., Hui, C. C., Nieves, E., Cohen, P. E., Osborne, L. R., Wada, T., Kunieda, T., Moens, P. B. and Penninger, J. M. (2003) Essential role of Fkbp6 in male fertility and homologous chromosome pairing in meiosis. Science. 300, 1291-1295.

141 Zhang, W., Zhang, S., Xiao, C., Yang, Y. and Zhoucun, A. (2007) Mutation screening of the FKBP6 gene and its association study with spermatogenic impairment in idiopathic infertile men. Reproduction. 133, 511-516.

142 Zhao, C., Avilés, C., Abel, R. A., Almli, C. R., McQuillen, P. and Pleasure, S. J. (2005) Hippocampal and visuospatial learning defects in mice with a deletion of frizzled 9 , a gene in the Williams syndrome deletion interval. Development. 132, 2917-2927.

143 Ranheim, E. A., Kwan, H. C., Reya, T., Wang, Y. K. Weissman, I. L. and Francke, U. (2005) Frizzled 9 knock out mice have abnormal B-cell development. Blood. 105, 2487 2494.

144 Cus, R., Maurus, D. and Kühl, M. (2006) Cloning and developmental expression of WSTF during Xenopus laevis embryogenesis. Gene Expr. Patterns. 6, 340-346.

145 Bozhenok, L., Wade, P. A. and Varga-Weisz, P. (2002) WSTFISWI chromatin remodeling complex targets heterochromatic replication foci. EMBO J. 21, 2231-2241.

146 Cavellán, E., Asp, P., Percipalle, P. and Farrants, A. K. (2006) The WSTF-SNF2 h chromatin remodeling complex interacts with several nuclear proteins in transcription. J. Biol. Chem. 281, 16264-16271.

147 Kitagawa, H., Fujiki, R., Yoshimura, K., Mezaki, Y., Uematsu, Y., Matsui, D., Ogawa, S., Unno, K., Okubo, M., Tokita A., Nakagawa, T., Ito, T., Ishimi, Y., Nagasawa, H., Matsumoto, T., Yanagisawa, J. and Kato, S. (2003) The chromatin remodeling complex WINAC targets a nuclear receptor to promoters and is impaired in Williams syndrome. Cell. 113, 905-917.

148 Zani, V. J., Asou, N., Jadayel, D., Heward, J. M., Shipley, J., Nacheva, E., Takasuki, K., Catovsky, D., Dyer, M. J. (1996) Molecular cloning of complex chromosomal translocation $\mathrm{t}(8 ; 14 ; 12)(\mathrm{q} 24.1 ; \mathrm{q} 32.3 ; \mathrm{q} 24.1)$ in a Burkitt lymphoma cell line defines a new gene (BCL7A) with homology to caldesmon. Blood. 87, 3124-3134.

$149 \mathrm{Li}$, J. and Wang, C. Y. (2008) TBL1-TBLR1 and beta-catenin recruit each other to Wnt target-gene promoter for tran- scription activation and oncogenesis. Nat. Cell Biol. 10, 160169.

150 Chen, P. C., Kuraguchi, M., Velasquez, J., Wang, Y., Yang, K., Edwards, R., Gillen, D., Edelmann, W., Kucherlapati, R. and Lipkin, S. M. (2008) Novel roles for MLH3 deficiency and TLE6-like amplification in DNA mismatch repair-deficient gastrointestinal tumorigenesis and progression. PLoS Genet. 4, e1000092. doi:10.1371/journal.pgen.1000092

151 Cairo, S., Merla, G., Urbinati, F., Ballabio, A. and Reymond, A. (2001) WBSCR14, a gene mapping to the Williams-Beuren syndrome deleted region, is a new member of the Mlx transcription factor network. Hum. Mol. Genet. 10, 617-627.

152 Merla, G., Howald, C., Antonarakis, S. E. and Reymond, A. (2004) The subcellular localization of the ChoRE-binding protein, encoded by the Williams-Beuren syndrome critical region gene 14, is regulated by 14-3-3. Hum. Mol. Genet. 13, $1505-1514$.

153 Li, M. V., Chang, B., Imamura, M., Poungvarin, N. and Chan, L. (2006) Glucose-dependent transcriptional regulation by an evolutionarily conserved glucose-sensing module. Diabetes. 55, 1179-1189.

154 Ma, L., Tsatsos, N. G. and Towle, H. C. (2005) Direct role of ChREBP.Mlx in regulating hepatic glucose-responsive genes. J. Biol. Chem. 280, 12019-12027.

155 Curtiss, M., Jones, C. and Babst, M. (2007) Efficient cargo sorting by ESCRT-I and the subsequent release of ESCRT-I from multivesicular bodies requires the subunit Mvb12. Mol. Biol. Cell. 18, 636-645.

156 Stuchell, M. D., Garrus, J. E., Müller, B., Stray, K. M., Ghaffarian, S., McKinnon, R., Kräusslich, H. G., Morham, S. G. and Sundquist, W. I. (2004) The human endosomal sorting complex required for transport (ESCRT-I) and its role in HIV-1 budding. J. Biol. Chem. 279, 36059-36071

157 Katzmann, D. J., Babst, M. and Emr, S. D. (2001) Ubiquitindependent sorting into the multivesicular body pathway requires the function of a conserved endosomal protein sorting complex, ESCRT-I. Cell. 106, 145-155.

158 Vos, M. J., Hageman, J., Carra, S. and Kampinga, H. H. (2008) Structural and Functional Diversities between Members of the Human HSPB, HSPH, HSPA, and DNAJ Chaperone Families. Biochemistry. 47, 7001-7011.

159 Wu, Y. Q., Bejjani, B. A., Tsui, L. C., Mandel, A., Osborne, L. R. and Shaffer, L. G. (2002) Refinement of the genomic structure of STX1A and mutation analysis in nondeletion Williams syndrome patients. Am. J. Med. Genet. 109, 121 124.

160 Yamakawa, T., Saith, S., Li, Y., Gao, X., Gaisano, H. Y. and Tsushima, R. G. (2007) Interaction of syntaxin $1 \mathrm{~A}$ with the Nterminus of Kv4.2 modulates channel surface expression and gating. Biochemistry. 46, 10942-10949.

161 Rickman, C., Medine, C. N., Bergmann, A. and Duncan, R. R. (2007) Functionally and spatially distinct modes of munc18syntaxin 1 interaction. J. Biol. Chem. 282, 12097-12103.

162 Kang, Y., Leung, Y. M., Manning-Fox, J. E., Xia, F., Xie, H., Sheu, L., Tsushima, R. G., Light, P. E. and Gaisano, H. Y. (2004) Syntaxin-1A inhibits cardiac KATP channels by its actions on nucleotide binding folds 1 and 2 of sulfonylurea receptor 2A. J. Biol. Chem. 279, 47125-47131.

163 Ohara-Imaizumi, M., Fujiwara, T., Nakamichi, Y., Okamura, T., Akimoto, Y., Kawai, J., Matsushima, S., Kawakami, H., Watanabe, T., Akagawa, K. and Nagamatsu, S. (2007) Imaging analysis reveals mechanistic differences between first- and second-phase insulin exocytosis. J. Cell Biol. 177, $695-705$.

164 Lam, P. P., Leung, Y. M., Sheu, L., Ellis, J., Tsushima, R. G, Osborne, L. R. and Gaisano H. Y. (2005) Transgenic mouse overexpressing syntaxin-1A as a diabetes model. Diabetes. 54, 2744-2754.

165 Fujiwara, T., Mishima, T., Kofuji, T., Chiba, T., Tanaka, K., Yamamoto, A. and Akagawa, K. (2006) Analysis of knock-out mice to determine the role of HPC-1/syntaxin 1A in expressing synaptic plasticity. J. Neurosci. 26, 5767-5776. 
166 Morita, K., Furuse, M., Fujimoto, K. and Tsukita, S. (1999) Claudin multigene family encoding four-transmembrane domain protein components of tight junction strands. Proc. Natl. Acad. Sci. USA. 96, 511-516.

167 Hewitt, K. J., Agarwal, R. and Morin, P. J. (2006) The claudin gene family: expression in normal and neoplastic tissues. BMC Cancer. 6, 186.

168 Bagherie-Lachidan, M., Wright, S. I. and Kelly, S. P. (2008) Claudin-3 tight junction proteins in Tetraodon nigroviridis: cloning, tissue-specific expression, and a role in hydromineral balance. Am. J. Physiol. Regul. Integr. Comp. Physiol. 294, R1638-R1647.

169 Prescott, J., Jariwala, U., Jia, L., Cogan, J. P., Barski, A., Pregizer, S., Shen, H. C., Arasheben, A., Neilson, J. J., Frenkel, B. and Coetzee, G. A. (2007) Androgen receptormediated repression of novel target genes. Prostate. 67,13711383

170 Pezet, M., Jacob, M. P., Escoubet, B., Gheduzzi, D., Tillet, E. Perret, P., Huber, P., Quaglino, D., Vranckx, R., Li, D. Y. Starcher, B., Boyle, W. A., Mecham, R. P. and Faury, G. (2008) Elastin haploinsufficiency induces alternative aging processes in the aorta. Rejuvenation Res. 11, 97-112.

171 Scott, R. W. and Olson, M. F. (2007) LIM kinases: function, regulation and association with human disease. J. Mol. Med. 85, 555-568.

172 Wang, J. Y., Frenzel, K. E., Wen, D. and Falls, D. L. (1998) Transmembrane neuregulins interact with LIM kinase 1, a cytoplasmic protein kinase implicated in development of visuospatial cognition. J. Biol. Chem. 273, 20525-20534.

173 Gray, V., Karmiloff-Smith, A., Funnell, E. and Tassabehji, M. (2006) In-depth analysis of spatial cognition in Williams syndrome: A critical assessment of the role of the LIMK1 gene. In-depth analysis of spatial cognition in Williams syndrome: A critical assessment of the role of the LIMK1 gene. Neuropsychologia. 44, 679-685.

174 Meng, Y., Zhang, Y., Tregoubov, V., Janus, C., Cruz, L., Jackson, M., Lu, W. Y., MacDonald, J. F., Wang, J. Y., Falls, D. L. and Jia, Z. (2002) Abnormal spine morphology and enhanced LTP in LIMK-1 knockout mice. Neuron. 35, 121 133.

175 Richter, N. J., Rogers, G. W. Jr., Hensold, J. O. and Merrick, W. C. (1999) Further biochemical and kinetic characterization of human eukaryotic initiation factor 4 H. J. Biol. Chem. 274 35415-35424.

176 Iwaki, S., Jensen, B. M. and Gilfillan, A. M. (2007) Ntal/Lab/ Lat2. Int. J. Biochem. Cell Biol. 39, 868-873.

177 Majka, J. and Burgers, P. M. (2004) The PCNA-RFC families of DNA clamps and clamp loaders. Prog. Nucleic. Acid. Res. Mol. Biol. 78, 227-260

178 Hoogenraad, C. C., Koekkoek, B., Akhmanova, A., Krugers, H., Dortland, B., Miedema, M., van Alphen, A., Kistler, W. M., Jaegle, M., Koutsourakis, M., Van Camp, N., Verhoye, M., van der Linden, A., Kaverina, I., Grosveld, F., De Zeeuw, C. I and Galjart, N. (2002) Targeted mutation of Cyln2 in the Williams syndrome critical region links CLIP-115 haploinsufficiency to neurodevelopmental abnormalities in mice. Nat. Genet. 32, 116-127.

179 van Hagen, J. M., van der Geest, J. N., van der Giessen, R. S. Lagers-van Haselen, G. C., Eussen, H. J., Gille, J. J., Govaerts, L. C., Wouters, C. H., de Coo, I. F., Hoogenraad, C. C., Koekkoek, S. K., Frens, M. A., van Camp, N., van der Linden, A., Jansweijer, M. C., Thorgeirsson, S. S. and De Zeeuw, C. I. (2007) Contribution of CYLN2 and GTF2IRD1 to neurological and cognitive symptoms in Williams Syndrome. Neurobiol. Dis. 26, 112-124.

180 Thompson, P. D., Webb, M., Beckett, W., Hinsley, T., Jowitt, T., Sharrocks, A. D. and Tassabehji, M. (2007) GTF2IRD regulates transcription by binding an evolutionarily conserved DNA motif 'GUCE'. FEBS Lett. 581, 1233-1242.

181 Palmer, S. J., Tay, E. S., Santucci, N., Cuc Bach, T. T., Hook, J., Lemckert, F. A., Jamieson, R. V., Gunnning, P. W. and Hardeman, E. C. (2007) Expression of Gtf2ird1, the Williams syndrome-associated gene, during mouse development. Gene Expr. Patterns. 7, 396-404.

182 Chimge, N. O., Makeyev, A. V., Ruddle, F. H. and Bayarsaihan, D. (2008) Identification of the TFII-I family target genes in the vertebrate genome. Proc. Natl. Acad. Sci. USA. 105, 9006-9010.

183 Ohazama, A. and Sharpe, P. T. (2007) TFII-I gene family during tooth development: candidate genes for tooth anomalies in Williams syndrome. Dev. Dyn. 236, 2884-2888.

184 Tassabehji, M., Hammond, P., Karmiloff-Smith, A., Thompson, P., Thorgeirsson, S. S., Durkin, M. E., Popescu, N. C., Hutton, T., Metcalfe, K., Rucka, A., Stewart, H., Read, A. P., Maconochie, M. and Donnai, D. (2005) GTF2IRD1 in craniofacial development of humans and mice. Science. 310, $1184-1187$

185 Young, E. J., Lipina, T., Tam, E., Mandel, A., Clapcote, S. J., Bechard, A. R., Chambers, J., Mount, H. T., Fletcher, P. J., Roder, J. C. and Osborne, L. R. (2008) Reduced fear and aggression and altered serotonin metabolism in Gtf2ird1targeted mice. Genes Brain. Behav. 7, 224-234.

186 Merla, G., Howald, C., Henrichsen, C. N., Lyle, R., Wyss, C., Zabot, M. T., Antonarakis, S. E. and Reymond, A. (2006) Submicroscopic deletion in patients with Williams-Beuren syndrome influences expression levels of the nonhemizygous flanking genes. Am. J. Hum. Genet. 79, 332-341.

187 Tassabehji, M., Metcalfe, K., Karmiloff-Smith, A., Carette, M. J., Grant, J., Dennis, N., Reardon, W., Splitt, M., Read, A. P. and Donnai, D. (1999) Williams syndrome: use of chromosomal microdeletions as a tool to dissect cognitive and physical phenotypes. Am. J. Hum. Genet. 64, 118-125.

188 Hoogenraad, C. C., Akhmanova, A., Galjart, N. and De Zeeuw, C. I. (2004) LIMK1 and CLIP-115: linking cytoskeletal defects to Williams syndrome. Bioessays. 26, 141-150.

189 van Hagen, J. M., Eussen, H. J., van Schooten, R., van Der Geest, J. N., Lagers-van Haselen, G. C., Wouters, C. H., De Zeeuw, C. I. and Gille, J. J. (2007) Comparing two diagnostic laboratory tests for Williams syndrome: fluorescent in situ hybridization versus multiplex ligation-dependent probe amplification. Genet. Test. 11, 321-327.

190 Howald, C., Merla, G., Digilio, M. C., Amenta, S., Lyle, R., Deutsch, S., Choudhury, U., Bottani, A., Antonarakis, S. E., Fryssira, H., Dallapiccola, B. and Reymond, A. (2006) Two high-throughput technologies to detect segmental aneuploidies identify new Williams-Beuren Syndrome patients with atypical deletions. J. Med.Genet. 43, 266-273.

191 Mizugishi, K., Yamanaka, K., Kuwajima, K. and Kondo, I. (1998) Interstitial deletion of chromosome 7q in a patient with Williams syndrome and infantile spasms. J. Hum. Genet. 43, $178-181$.

192 Wu, Y. Q., Nickerson, E., Shaffer, L. G., Keppler-Noreuil, K. and Muilenburg, A. (1999) A case of Williams syndrome with a large, visible cytogenetic deletion. J. Med. Genet. 36, $928-$ 932.

193 Morimoto, M., An, B., Ogami, A., Shin, N., Sugino, Y., Sawai, Y., Usuku, T., Tanaka, M., Hirai, K., Nishimura, A., Hasegawa, K. and Sugimoto, T. (2003) Infantile spasms in a patient with williams syndrome and craniosynostosis. Epilepsia. 44, 1459-1462.

194 Marshall, C. R., Young, E. J., Pani, A. M., Freckmann, M. L., Lacassie, Y., Howald, C., Fitzgerald, K. K., Peippo, M., Morris, C. A., Shane, K., Priolo, M., Morimoto, M., Kondo, I., Manguoglu, E., Berker-Karauzum, S., Edery, P., Hobart, H. H., Mervis, C. B., Zuffardi, O., Reymond, A., Kaplan, P., Tassabehji, M., Gregg, R. G., Scherer, S. W. and Osborne, L. R. (2008) Infantile spasms is associated with deletion of the MAGI2 gene on chromosome 7q11.23-q21.11. Am. J. Hum. Genet. 83, 106-111. 